\title{
Uma Utopia Brasileira: Vargas e a Construção do Estado de Bem-Estar numa Sociedade Estruturalmente Desigual
}

\section{Adalberto Cardoso}

Professor e pesquisador do Instituto de Estudos Sociais e Políticos (IESP), da Universidade do Estado do Rio de Janeiro (UERJ). E-mail: acardoso@iesp.uerj.br

Getúlio foi tudo para o nosso povo, foi tudo pro pessoal da lavoura. [...] Antes de Getúlio não tinha lei, nós éramos bicho. A Princesa Isabel só assinou, Getúlio foi quem libertou a gente do jugo da escravatura (Cornélio Cancino, descendente de escravos, em depoimento ao projeto "Memórias do Cativeiro", reproduzido por Rios e Mattos, 2005:56).

\section{INTRODUÇÃO}

\begin{abstract}
A persistente desigualdade brasileira continua a desafiar a imaginação sociológica. Não é para menos. Em 1872, o índice de Gini, uma das possíveis medidas da desigualdade de distribuição de renda, pode ter sido de 0,56 , segundo estimativas recentes ${ }^{1}$. Quase cinquenta anos depois (1920), o índice parece ter piorado, chegando a 0,62 ${ }^{2}$. Em 1976, outros cinquenta anos decorridos, tínhamos o mesmo valor, 0,62. E, em 2006, o índice era de 0,57, equivalente, então, ao encontrado 130 anos antes. Essa desconcertante e longeva dança de números sugere cautela aos que se debruçam sobre o tema em busca de causalidade fácil, restrita a dinâmicas recentes. Nesses 130, anos o Brasil deixou de ser uma economia agrária para se tornar uma das mais importantes sociedades industriais do mundo, e essa mudança estrutural não resultou, como seria de se esperar de processos de modernização semelhantes, em uma sociedade mais igualitária, ou pelo menos em uma socie-
\end{abstract}

DADOS - Revista de Ciências Sociais, Rio de Janeiro, vol. 53, nº 4, 2010, pp. 775 a 819. 
dade na qual a maioria de seus membros já não compartilhasse a condição de pobreza, ou de restrição de liberdade decorrente da penúria das condições de vida.

Este estudo se pretende uma pequena contribuição no esforço, persistente e ainda atual, de decifração do enigma da também persistente desigualdade brasileira. Emprego a sociologia do trabalho como chave inicial de interpretação, para, em seguida, propor uma revisão do que se conhece como "Era Vargas", seu significado e alcance histórico, tendo em vista a reprodução das desigualdades no tempo. Em primeiro lugar, apresento os parâmetros da interpretação do Brasil moderno propostos por Juarez Brandão Lopes nos anos 1960 e as derivações mais importantes do debate que se seguiu à publicação de seus estudos empíricos com operários fabris em Minas Gerais e São Paulo. Sugiro que, se lido em chave menos preconceituosa, informada pelos achados da historiografia mais recente produzida no país, esse corpo interpretativo tem grande poder explicativo sobre a dinâmica das desigualdades entre nós, bem além do que imaginavam seus autores originais. Continuando, analiso aspectos selecionados do programa varguista de "valorização integral do homem brasileiro", a fim de chamar a atenção para seus limites e consequências para a reprodução das desigualdades no tempo. Argumento que a pobreza estrutural do Estado foi um dos elementos responsáveis por minar no berço as possibilidades de sucesso do empreendimento varguista. Ainda assim, a instituição da legislação social e trabalhista mudou inteiramente a relação do Estado brasileiro com seu povo. Sustento que a "cidadania regulada" gerou nos trabalhadores a expectativa de proteção social, alimentando uma promessa de integração cidadã que, embora não tenha se efetivado, cumpriu a tarefa de incorporar, finalmente mas não para sempre, os trabalhadores como artífices do processo brasileiro de construção estatal. A partir de Vargas, os nacionais descobriram que valia a pena lutar pela faticidade do Estado enquanto ordem jurídica que lhes prometia proteção e bem-estar social. Essa luta, por sua vez, moldou sua identidade social e política, pois, num país com $80 \%$ da população situada abaixo da linha da pobreza, a promessa dos direitos era uma promessa utópica, capaz de disputar corações e mentes com outras promessas (como a socialista ou a comunista) em posição bastante privilegiada, porque corporificada em instituições e na ordem jurídica estatal, sobretudo em sua capacidade de reprimir legitimamente a dissidência. Como promessa jamais universalizada, a "cidadania regulada" reve- 
lou-se importante, multidimensional e institucionalizado mecanismo de reprodução de desigualdades.

\section{"O AJUSTAMENTO DO TRABALHADOR À INDÚSTRIA"}

É provável que o estudo de maior impacto na sociologia do trabalho brasileira da primeira metade dos anos 1960 tenha sido um pequeno artigo de Juarez Brandão Lopes, intitulado "O ajustamento do trabalhador à indústria: mobilidade social e motivação", escrito com base em pesquisa realizada em 1957 e publicado em livro organizado por B. Hutchinson em 1960, de nome Mobilidade e Trabalho. O artigo seria reeditado em 1964 num livro divisor de águas, Sociedade Industrial no Brasil. Não é difícil aquilatar o impacto desse artigo e, depois, do livro, na interpretação da sociedade do trabalho entre nós, já que boa parte da literatura dos anos 1960 e 1970 no país tomou-os, de um modo ou de outro, como referência. No que se segue, recupero essa tradição para propor uma reflexão mais geral sobre a incorporação dos trabalhadores na dinâmica capitalista brasileira. Em seguida, utilizo evidências trazidas pelo próprio Lopes, às quais agrego outras, para propor leitura alternativa dos processos por ele apresentados como aspectos da "crise do Brasil arcaico".

No texto em tela, Lopes se filia desde logo à tradição weberiana, tal como apropriada por Parsons nos Estados Unidos, e realiza um estudo clássico de mudança social. Seu interesse são os ajustamentos de comportamento exigidos dos trabalhadores migrantes do campo quando incorporados à indústria, num processo que combina, em geral, mobilidade geográfica e social, tendo, assim, grande potencial para afetar a totalidade da vida das pessoas envolvidas.

Lopes opera com um conjunto de pressupostos muito sólidos, embora nem sempre explícitos em seu texto. Para ele, o Brasil estava às portas de se transformar numa sociedade industrial, e, por isso, era essencial à sociologia compreender os mecanismos dessa transformação, sobretudo seu impacto nas populações que viviam do trabalho, no campo ou na cidade. Dominando com maestria a produção sociológica, em especial a norte-americana sobre o industrialismo, seus males e dilemas organizacionais e sociais, ele estava seguro de que a industrialização tinha vindo para ficar, e que transformaria para sempre a realidade brasileira e os padrões de incorporação de sua população à dinâmica capitalista. 
Seu arcabouço explicativo era simples e elegante, como de resto o eram as teorias da modernização. Ele partia de um tipo ideal de sociedade tradicional, em que "os fatos econômicos derivam de um sistema de relações pessoais" (p. 25) ${ }^{3}$, e os princípios básicos que sustentam as trocas são a reciprocidade e a redistribuição, e não o mercado. A matriz da explicação é Karl Polanyi e sua ideia de que a economia, nas sociedades tradicionais, está "submergida nas suas relações sociais" (ibid.), tradução de Lopes para a conhecida categoria polanyiana de "embededness". Nessa sociedade, o trabalho é assegurado pela obrigação moral das pessoas às normas da sobrevivência da comunidade, das quais dependem a autoestima, a satisfação das necessidades e a sobrevivência individual.

Essa sociedade contrapõe-se àquela em que o mercado é o fato central dos sistemas econômico e social. A "atividade aquisitiva é aprovada; a expectativa social é que as pessoas procurem a consecução dos seus interesses econômicos individuais. A conduta econômica [...] deve ser racional" (p. 27). O sistema econômico é aberto, já que cada qual busca sua própria satisfação individual, por contraposição ao relativo ensimesmamento da sociedade tradicional; e o preço de mercado, e não normas sociais, é o principal elemento de coordenação das ações.

Assim, o problema de pesquisa está de antemão delineado: a vinda de pessoas das zonas rurais para as cidades é a passagem, sem mediações, de um ambiente próximo das sociedades tradicionais para outro no qual impera a economia racional de mercado. Isso gera um problema de ajustamento de expectativas e padrões de comportamento, característico dos primórdios da industrialização no Brasil e do processo de construção da classe operária entre nós.

Para estudar esse problema, Lopes elege uma fábrica de porte médio em São Paulo, na qual apenas 7,5\% dos trabalhadores eram paulistanos. Outros $28 \%$ eram estrangeiros e os $63 \%$ restantes eram migrantes nacionais, $21 \%$ dos quais do Nordeste. Em razão da grande concentração de nordestinos, Lopes reconstrói rapidamente a sociabilidade no meio rural de origem dos operários, para mostrar que eles de fato provinham de uma sociedade de tipo tradicional. E sustenta que haveria, nas classes rurais, em especial nas que vêm do Nordeste, "um valor cultural de trabalhar por conta própria, ser independente, valer-se da própria iniciativa e não submeter-se diretamente a ninguém" (p. 36). Além disso, poucos tinham intenção de permanecer em São Paulo. Seu 
sonho era juntar algum dinheiro e retornar ao campo, onde tinham deixado suas famílias. Esse padrão se distinguia apenas em parte do caso dos migrantes do interior de São Paulo, que ficariam no destino "se desse certo", mas, caso contrário, voltariam (pp. 38-39).

A partir desse ponto, o trabalho de Lopes poderia ter sido escrito como dedução pura e simples das teorias da modernização. Depois de mostrar que o migrante nordestino acaba se fixando na cidade - porque o trabalho em fábrica, apesar de tudo, é mais leve do que o eito, e a comparação entre a vida atual, vista como difícil, com a vida anterior, vista como muito mais difícil e insegura, é favorável à cidade -, o autor insiste em que "[a] orientação psicológica dos entrevistados de origem rural é claramente para fora do sistema industrial" (pp. 44-45) e que o desejo de todos é "trabalhar por conta própria", porque não se depende de horário, não se depende de chefe. Mas então ele oferece uma evidência interessante, da qual ele mesmo não tira as devidas consequências, mas que terá impacto duradouro sobre a sociologia brasileira posterior. Um cearense entrevistado por ele diz que "homem que pica cartão não tem futuro; pessoa que trabalha por conta própria é que pode melhorar" (p. 46). Lopes vê nessa fala a expressão cabal do desajustamento do trabalhador rural de migração recente à sociedade industrial e atribui a esse desajustamento a dificuldade (na verdade, impossibilidade) de constituição de uma solidariedade de classe tipicamente operária, isto é, tal como a que se desenvolveu no modelo clássico de capitalismo industrial.

Talvez a mais provocadora análise alternativa das consequências desses achados de Lopes tenha sido formulada por Alain Touraine, num texto pequeno mas também muito influente, denominado "Industrialização e consciência operária em São Paulo", publicado em 1961 na revista Sociologie du Travail. Tendo por referência os trabalhos de Lopes, Fernando Henrique Cardoso (que, por sua vez, se baseava em Lopes) e o Florestan Fernandes de Mudanças Sociais no Brasil, Touraine sustenta que o desejo de melhorar de vida, ao contrário do que queriam Lopes, Florestan Fernandes ou Fernando Henrique Cardoso, é uma conduta de mobilidade (p. 396) ${ }^{4}$, expressão de atitudes modernas de certo tipo, que configuram o que ele denominou "consciência de mobilidade". Touraine concorda que o peso das tradições pré-industriais impede que esses trabalhadores se identifiquem com a classe operária. Mas, ao lado desse peso, mais importante é "a crença, que pode ser utópica, nas chances que lhes oferecem a vida urbana e o trabalho industrial; uma 
vontade de mobilidade que não se satisfaz com um trabalho instável e não qualificado e que os conduz a esperar que um dia eles superarão a condição presente" (p. 396). Essa consciência de mobilidade é prenhe de consequências para a dinâmica social e política da classe operária, segundo Touraine, porque ela "se acompanha de uma relativa integração das atitudes, nas quais o aspecto mais frequente pode ser o não conformismo utópico, isto é, a união da submissão tradicional com a esperança nas possibilidades de ascensão do indivíduo e, mais ainda, de seus filhos" (p. 397). Nesse processo, a situação pretérita e a presente são reinterpretadas em função da esperança de melhoria de vida. E, como essa consciência liga estreitamente a mobilidade individual e o desenvolvimento coletivo do país, a consequência é a legitimação da sociedade global, que fica, assim, protegida contra uma sublevação revolucionária.

Touraine agrega ainda outros argumentos importantes, igualmente apropriados pelo debate posterior, como a ideia de que no Brasil a urbanização precedeu a industrialização, e, com isso, as massas vindas do campo não encontraram na indústria seu destino primordial. O processo, ademais, gerou marginalização e pobreza de grandes contingentes de trabalhadores, além de desigualdade e competição pelos poucos postos de trabalho industriais, contribuindo para manter os salários sempre baixos etc.

Os trabalhos de Lopes e Touraine influenciaram fortemente a pesquisa posterior, embora de maneira talvez não antecipada pelos dois autores. Leôncio Martins Rodrigues, por exemplo, em estudos muito influentes realizados em fábricas de multinacionais de automóveis ${ }^{5}$, então tratadas como empregando o setor mais moderno do operariado, encontrou atitudes operárias tradicionais, consciência de mobilidade e aversão ao trabalho industrial, além de incapacidade de ação coletiva solidária e ausência de consciência de classe. Fernando Henrique Cardoso, com base nos mesmos estudos, sustentou ideia ainda mais forte no seu "Proletariado no Brasil: situação e comportamento social", publicado originalmente em 1962. Para ele, os trabalhadores rurais deixaram o campo menos em busca de ascensão social do que para fugir da miséria (Cardoso, 1969[1962]:116), visto que seriam mais conformados diante do destino e mais dispostos a aceitar as condições precárias de trabalho na indústria. A intensa migração do campo para a cidade, concentrada no tempo, teria produzido um "'efeito de amortecimento' sobre o grau de consciência da situação [...] e, consequentemente, so- 
bre as possibilidades de empreendimento de ações reivindicatórias no plano da empresa e da sociedade global" (p. 117). Por essa razão, além das apontadas por Lopes e Touraine, esse operariado dificilmente chegaria a agir conforme seu interesse específico de classe, não se colocando "a questão do poder como a pedra de toque de uma ação proletária historicamente consciente de seu papel" (p. 121).

A historiografia brasileira poria por terra esses argumentos nos anos 1980, como é sabido. A partir do estudo fundador de Paoli et alii (1983), o encontro dos migrantes com o mundo do trabalho industrial deixou de ser tratado como inautêntico, por não resultar em atitudes revolucionárias de uma classe "consciente de seu papel"6. Segundo essa interpretação, a classe operária no Brasil seria definida, pelos estudos precedentes, na negativa: não tinha consciência de classe, não agia politicamente para transformar a sociedade, não era moderna etc. Impossível não concordar com essa crítica. Contudo, parece-me que ela tampouco pode ser levada longe demais. Os estudos mencionados anteriormente, embora carreguem a marca da inautenticidade que a crítica posterior identificou, trazem elementos que, lidos em outra chave, em meu ponto de vista, expressam o que de fato ocorreu no Brasil depois de 1930. Refiro-me muito especialmente ao que em Touraine aparece como "crença utópica" nas possibilidades de mobilidade social abertas pela sociedade brasileira em mudança. Aqui, sugiro que essa ideia tem muita força, se lida em perspectiva diversa, isto é, se referida ao programa varguista de integração social baseado na promessa da "cidadania regulada". Senão, vejamos.

\section{ASPECTOS DE UMA CONSTRUÇÃO UTÓPICA}

A utopia varguista ganhou muitos tradutores ao longo dos primeiros 15 anos de poder de Vargas, mas poucos foram tão sistemáticos e incisivos quanto Oliveira Vianna. Sua obra não é vasta, mas é muito consistente, em especial aquela dedicada a propagandear os feitos da Revolução de 1930. Seleciono para análise o conjunto de conferências, ensaios e artigos de jornal trazidos a público entre 1932 e 1940 (período em que participou diretamente da gestão do que ele mesmo denominou "Governo revolucionário"), depois reunidos em Oliveira Vianna (1951). Nesse extraordinário libelo de propaganda, somos expostos ao sumo da ideologia da promoção do homem brasileiro por meio da política social da Revolução, que vinha enfim resgatar a nacionalidade de seus quatro séculos de história. Para Oliveira Vianna, a obra social de 
Vargas tinha um sentido corretivo, ou saneador, dos males de uma civilização que, por imposições da natureza hostil do vasto território em que vicejou, consolidou-se como carente de ossatura e de mecanismos promotores de solidariedade social. Oliveira Vianna, na verdade, avalia a obra varguista, de que ele também era artífice, sob a ótica de sua própria interpretação do Brasil, presente em trabalhos seminais como Instituições Políticas Brasileiras e, muito particularmente, Populações Meridionais do Brasil. Segundo essa interpretação, o povo, até 1930, havia sido esquecido pelas instituições civilizatórias, abandonado à própria sorte num ambiente hostil à vida coletiva, o que o obrigava à vinculação individual e submissa ao poder privado de caudilhos locais, senhores dos escassos recursos materiais e simbólicos da vida comunitária:

O homem que não tem terras, nem escravos, nem capangas, nem fortuna, nem prestígio, sente-se aqui, praticamente, fora da lei. Nada o ampara. Nenhuma instituição, nem nas leis, nem na sociedade, nem na família, existe para a sua defesa. Tudo concorre para fazê-lo um desiludido histórico, um descrente secular na sua capacidade pessoal para se afirmar por si mesmo. [...] O que os quatro séculos de nossa evolução lhe ensinam é que os direitos individuais, a liberdade, a pessoa, o lar, os bens dos homens pobres só estão garantidos, seguros e defendidos, quando têm para ampará-los o braço possante do caudilho local. Essa íntima convicção de fraqueza, de desamparo, de incapacidade se radica na sua consciência com a profundeza e a tenacidade do instinto (1922[1918]:151).

A eloquência da formulação não deve deixar dúvidas: a sociabilidade no início do V século brasileiro (como Oliveira Vianna gostava de nomear o século XX) era vista como caudatária dessa herança, radicada no povo brasileiro com "a tenacidade do instinto"; portanto, passada de uma a outra geração através dos séculos. Mas por que esse povo desamparado se submetia aos poderosos locais? Por necessidade, obviamente, mas também porque esse povo era bondoso, indulgente, pacífico, "feito de amabilidade, generosidade e doçura cristã" (Oliveira Vianna, 1951:58). A consequência óbvia é que do povo não se devia esperar movimentos violentos para a melhoria de sua própria penúria e fraqueza. Entre nós, a luta de classe não encontrou terreno fértil, apesar de seus efeitos em geral benéficos em termos de construção da solidariedade social, quando resultante de dinâmica social diferente da brasileira ${ }^{7}$. Libertar o povo do jugo dos poderosos locais e promovê-lo 
à cidadania plena era tarefa civilizatória que cabia ao Estado, para o que este não precisou "lutar contra linhas de cor, contra antagonismos de classes, contra ódios de raças" (ibidem:56). Resulta que a tarefa da Revolução, diferentemente dos países europeus, não foi assegurar a paz social, já de si garantida pela índole do povo, mas sim a justiça social, barrada pela natureza individualizante e degradante de nosso processo civilizatório.

Oliveira Vianna propagandeia um artifício, uma engenharia revolucionária voltada à integração do Brasil no "movimento incoercível, de extensão universal, que constitui a política de restauração das massas trabalhadoras na posse e na consciência da sua nobreza humana" (idem:54). A palavra forte dessa engenharia é, não casualmente, inclusão. Tendo estado excluídos da fruição das benesses civilizatórias, os trabalhadores sob Vargas teriam sido triplamente incluídos: na firma, por meio da estabilidade no emprego, o que gerou compromisso mútuo entre as classes pelo bem-estar de uns e a prosperidade de outros; no Estado, por meio da participação nos sindicatos como órgãos estatais e nos mecanismos corporativos de tomada de decisão, que acolhiam também as classes superiores; e na sociedade de consumo, aspecto garantido pela instituição do salário mínimo (idem:112 e ss.) e da previdência social, por ele chamada de propriedade social disponível aos trabalhadores, que assegurou bem-estar material na velhice e na doença. Aos trabalhadores, então, teriam sido dadas "todas as condições materiais e morais de segurança e conforto, de tranquilidade e justiça, de independência e dignidade" (idem:55-56), de tal modo que eles "sentem por toda parte o carinho do Estado, a ação vigilante de sua tutela e de sua assistência". Mas essa assistência, importante salientar, não tinha a forma dos "óbolos da caridade, que humilhavam o assistido", e sim a forma das "prestações de direito, reconhecidas, asseguradas e ministradas pelo poder público" (p. 50). O autor não tem dúvida: a revolução trouxe aos trabalhadores "segurança jurídica" (p. 71), além de ter promovido a elevação e dignificação progressiva das classes trabalhadoras dentro do regime capitalista. "Isso quer dizer, porém: elevação e dignificação conseguidas, não suprimindo as escalas de hierarquia social, não eliminando as classes superiores, não nivelando todas as categorias da sociedade [...] mas sim, fazendo as classes trabalhadoras partilharem progressivamente das vantagens e benesses com que a nossa civilização vem assegurando, há mais de um século, o conforto, o bem-estar e a dignidade humana e social das classes superiores" (p. 106). 
Entretanto, no mesmo conjunto de textos apologéticos de sua própria empreitada, Oliveira Vianna reconhece que a "enumeração das benemerências ou serviços, prestados pelas nossas instituições de previdência social e sindicais, representa um quadro nem sempre conforme aos fatos da realidade atual" (1951:127). Reconhece que a previdência social paga benefícios insuficientes à subsistência, que os serviços médicos e ambulatoriais não estão à altura de suas promessas, que o programa de casa própria para operários esbarrava em problemas de crédito etc. Mas um "juízo justo dessas instituições" devia levar em conta não o fato de sua penúria atual, mas sim as "formidáveis possibilidades que elas contêm em potencial" (idem:128). Oliveira Vianna não se resigna diante da escassez real de recursos do país, que desenhava instituições incapazes de cumprir suas promessas diante da enormidade das carências do povo que o mesmo Estado queria promover à cidadania. O desenho legal dessas instituições era justo em si mesmo, e sua eficiência se provaria no futuro, para o que o trabalhador devia ter paciência. Os limites estruturais à vigência da obra saneadora, pois, eram vistos como superáveis por obra do próprio Estado.

Vargas, muito especialmente o Vargas ditador, esteve sempre consciente do aspecto civilizatório do direito do trabalho que ele instituía, mas tinha melhor clareza do que Oliveira Vianna sobre seus limites num país como o Brasil. Em 1941, em engenhoso discurso proferido no Primeiro de Maio - momento em que o ditador costumava informar os trabalhadores, anualmente, sobre o andamento de "sua" obra social, isto é, os novos direitos "dadivosamente" agregados ao sempre incompleto edifício de "promoção do homem brasileiro" -, ele pregaria em favor da fixação do homem no campo, embora não necessariamente por meio de uma reforma agrária. Sem aquela fixação, o Brasil correria o risco de "assistir ao êxodo dos campos e superpovoamento das cidades - desequilíbrio de consequências imprevisíveis, capaz de enfraquecer ou anular os efeitos da campanha pela valorização integral do homem brasileiro, para dotá-lo de vigor econômico, saúde física e energia produtiva". E diria ainda, dirigindo-se aos milhares de trabalhadores que lotavam o estádio do Vasco da Gama, no Rio de Janeiro:

Temos a enfrentar, corajosamente, sérios problemas de melhoria das nossas populações, para que o conforto, a educação e a higiene não sejam privilégio de regiões ou de zonas. Os benefícios que conquistastes devem ser ampliados aos operários rurais, os que, insulados nos sertões, vivem distantes das vantagens da civilização. [...] 
Não é possível mantermos a anomalia tão perigosa como a de existirem camponeses sem gleba própria, num país onde os vales férteis como a Amazônia permanecem incultos e despovoados de rebanhos, extensas pastagens, como as de Goiás e Mato Grosso. É necessário à riqueza pública que o nível de prosperidade da população rural aumente para absorver a crescente produção industrial; é imprescindível elevar a capacidade aquisitiva de todos os brasileiros - o que pode ser feito aumentando-se o rendimento do trabalho agrícola (Vargas, 1941:261-262).

Vargas, como se vê, tinha exata noção das injunções estruturais a seu projeto civilizatório. O Brasil era um país rural, com pouco menos de $3 \%$ de proprietários de terra - apesar dos $70 \%$ de brasileiros que viviam no campo, um terço dos quais assalariados e dois terços compondo diferentes regimes de colonato, parceria, posse ou pequena propriedade da terra, a maioria deles disposta a arribar ao menor sinal de que a vida poderia ser melhor em outro lugar. Fixar as populações rurais, pois, não seria possível se ao trabalhador rural não fossem estendidas as benesses da civilização que a Revolução construía nas cidades.

Ademais, um mundo rural pujante constituiria o mercado interno para o produto da indústria nascente, e, para tanto, o projeto não era outro senão colonizar a Amazônia. Isto é, impossibilitado de enfrentar o problema da propriedade da terra num país ainda refém das oligarquias agrárias (outra restrição importante a seu projeto saneador), Vargas via como única alternativa expandir a fronteira agrícola, ocupar a Amazônia, área de terras devolutas passíveis de políticas públicas de colonização ${ }^{8}$, ou seja, era preciso estabelecer políticas que não tocassem na estrutura fundiária consolidada no restante do país, nem nos interesses agrários ainda fortemente representados no aparelho de Estado. O discurso, nesse sentido, é o reconhecimento resignado da própria fragilidade do poder central vis-à-vis os poderes agrários ainda prevalecentes ${ }^{9}$.

Na verdade, a impotência diante de inexoráveis e incontroláveis dinâmicas populacionais há muito tirava o sono do estadista gaúcho. Em discurso pronunciado na Bahia em 11 de agosto de 1933, ao analisar as consequências do fim da escravidão para as populações diretamente afetadas, Vargas diria que, nas caatingas, viviam

populações rurais empobrecidas, ao léu das circunstâncias do clima e à míngua de recursos, vegetam desenraizadas, por vezes quase nômades, vivendo, dia por dia, jungidas à voracidade dos novos senhores 
que lhes exploram o trabalho rude, como se fossem compostas de retardatários servos da gleba.

Agravando semelhante desorganização, verificou-se o êxodo dos habitantes do interior, atraídos pelas ilusórias facilidades de trabalho abundante e bem recompensado, para os centros urbanos de vida intensa. $\mathrm{O}$ proletariado das cidades aumentou desproporcionadamente, originando o pauperismo e todos os males decorrentes do excesso de atividades sem ocupações fixas (1938, vol. 2:115).

Era esse mesmo pauperismo e seus males (dentre eles, obviamente, o risco de os pobres sucumbirem ao proselitismo comunista) que Vargas temia em 1941, daí a necessidade de se fixar o homem no campo.

Vargas tampouco ignorava as injunções materiais do Estado que herdara da Velha República, apesar da recorrente apologia de sua própria obra de construção estatal. Assim, ao fazer um balanço de dez anos de governo em discurso proferido no Aeroporto Santos Dumont durante banquete oferecido ao ditador "pelas classes conservadoras e trabalhadoras" em 11 de novembro do mesmo ano de 1941, regozijou-se de ter arrecadado em impostos, em 1939, o dobro do que fora extraído em 1930 e de ter despendido quase o dobro de dez anos antes (1941:170). Ele não mentia, já que a arrecadação de fato quase duplicara em moeda nacional; mas não dizia propriamente a verdade, se deflacionarmos a receita e a ponderarmos pelo tamanho da população que ele queria promover com suas políticas sociais. Nesse novo quadro, em 1930 a arrecadação federal per capita havia sido de 0,90 libras esterlinas, e a de 1939, de 1,18 libras. Aumento de quase 30\% em relação a 1930, mas bem longe do dobro propagandeado ${ }^{10}$. Ocorre que, se em dez anos a arrecadação crescera, a população também, e a taxas altas, o que terminou por anular parte dos efeitos da melhoria da capacidade arrecadadora do Estado vis-à-vis as carências da população. Contudo, também é verdade que, em mil réis, a despesa de 1939 foi quase duas vezes a de 1930 (4.3 milhões de contos de réis contra 2.5 milhões), mas em libras esterlinas o valor foi de 61 milhões, contra 51 milhões de dez anos antes. Ou seja, o aumento foi de perto de $20 \%$ em termos reais. Mas como a população também cresceu $20 \%$ no período, o gasto per capita foi exatamente o mesmo em 1930 e 1939: $£ 1,35$ por habitante.

Seja como for, ao colocar no centro de seu projeto de poder o enfrentamento da questão social, mesmo diante de injunções estruturais multivariadas, Vargas e aliados, sobretudo os tenentes, a quem o tema era 
caro desde os primórdios de suas mobilizações ${ }^{11}$, não inventaram a regulação estatal na chave dos direitos sociais de maneira descolada do real, como propôs, por exemplo, John French, em livros de 2001 e 2004. Mesmo que o mundo urbano acolhesse não mais do que 30\% da população brasileira, e que, desta, porcentagem diminuta se empregasse na indústria, alvo prioritário da regulação varguista, esta não se antecipou aos fatos, estando, na verdade, perfeitamente em dia com a ameaça visível do pauperismo que o êxodo rural vinha provocando nas grandes cidades. Assim, em 1940, calculada em relação à população economicamente ativa, a proporção de operários industriais ultrapassava os $26 \%$ no Distrito Federal (isto é, a cidade do Rio de Janeiro) e os $38 \%$ em São Paulo ${ }^{12}$; e, se considerarmos apenas os homens, é provável que se chegasse a 30\% dos ocupados no Distrito Federal e mais de 40\% em São Paulo $^{13}$. Ainda no Distrito Federal, excluindo-se os empregados domésticos, 75,6\% dos ocupados eram assalariados. A questão social especificamente moderna, parteira de revoluções sociais e dos movimentos de reforma que desaguaram na legislação social europeia, era visível no Rio de Janeiro, capital do país, e em São Paulo, já importante centro industrial, e era a ela que Vargas pensava estar respondendo ao propor seu edifício legal de proteção social. Como, porém, o Estado em transformação permanecia raquítico em termos da capacidade de implementar suas políticas, uma coisa era instituir normas legais, e outra bem diferente era dar-lhes efetividade. Essa tarefa coube, em grande medida, aos próprios trabalhadores, tanto individualmente, nos tribunais do trabalho ou na resistência miúda no cotidiano das empresas, quanto por meio de suas instituições representativas, isto é, os sindicatos, moldados pelo mesmo Vargas ${ }^{14}$.

\section{A "CIDADANIA REGULADA" E ALÉM}

A obra legislativa de Vargas não será objeto de análise aqui. A literatura sobre isso já é bastante alentada, e, embora haja substancial controvérsia quanto ao significado da legislação, não é tanto o caso quanto ao seu conteúdo ${ }^{15}$. Neste passo, gostaria apenas de apontar a plausibilidade de uma interpretação sobre aquela obra legislativa de proteção social, para o que parto da premissa de que o leitor conhece minimamente suas linhas gerais, que incluem a instituição de um salário mínimo, jornada de trabalho, descanso semanal remunerado, férias, proteção ao trabalho da mulher e do menor, aposentadoria etc. Para o que proponho aqui, esse arcabouço interessa não tanto por sua real ou pretensa efetividade, mas pelo significado que adquiriu na dinâmica soci- 
al mais geral, significado, de meu ponto de vista, ainda não atentado pela literatura sobre o tema. Tomo como ponto de partida o conceito de "cidadania regulada", para mostrar que esta constituiu uma promessa de incorporação social das massas até então desdenhadas pelo processo de construção da nação, promessa de grande impacto sobre os projetos, esperanças, horizontes de expectativas e sobre a práxis das populações que vivem do trabalho no país, de consequências duradouras para a sociabilidade capitalista de modo geral e para a reprodução das desigualdades ao longo do tempo.

O conceito de "cidadania regulada" é elemento inarredável do arsenal analítico disponível sobre a era Vargas, que encapsula, numa ideia forte e ao mesmo tempo simples, enorme conjunto de significados. A formulação de Wanderley Guilherme dos Santos é muito conhecida, mas vale a pena reproduzi-la por inteiro, para melhor compreensão do que proponho aqui:

Por cidadania regulada entendo o conceito de cidadania cujas raízes encontram-se não em um código de valores políticos, mas em um sistema de estratificação ocupacional, e que, ademais, tal sistema de estratificação ocupacional é definido por norma legal. Em outras palavras, são cidadãos todos aqueles membros da comunidade que se encontram localizados em qualquer uma das ocupações reconhecidas e definidas em lei. A extensão da cidadania se faz, pois, via regulamentação de novas profissões e/ou ocupações, em primeiro lugar, e mediante ampliação do escopo dos direitos associados a essas profissões, antes que por expansão dos valores inerentes ao conceito de membro da comunidade. A cidadania está embutida na profissão e os direitos do cidadão restringem-se aos direitos do lugar que ocupa no processo produtivo, tal como reconhecido por lei. Tornam-se pré-cidadãos, assim, todos aqueles cuja ocupação a lei desconhece [...]. O instrumento jurídico comprovante do contrato entre o Estado e a cidadania regulada é a carteira profissional, que se torna, em realidade, mais do que uma evidência trabalhista, uma certidão de nascimento cívico (Santos, 1979:75-76).

$\mathrm{Ou}$, dizendo simplesmente, "quem tem ofício, tem benefício", como consagrou Angela de Castro Gomes (1988:189 e ss.). O que pretendo propor é que, se, na definição de "cidadania regulada", levarmos em conta não apenas os direitos associados à condição de trabalhador inserido no setor formal da economia (ou seja, as profissões reconhecidas por lei), mas a totalidade do projeto varguista de promoção integral do homem brasileiro, tal como efetivamente vivenciado pelos destinatários des- 
se projeto, a cidadania deixa de aparecer como um conjunto de direitos que demarcasse, para sempre, incluídos e excluídos da ordem em construção. Ela passa a denotar, antes, uma ordem porosa e fluida, cujas portas de entrada se abriam e se fechavam várias vezes ao longo das trajetórias de vida dos que a ela se candidatavam, e a inclusão no mundo dos direitos podia ser bem efêmera, assim como a exclusão dele, de tal modo que inclusão real, exclusão momentânea ou permanente e renovadas expectativas de nova inclusão eram parte do mesmo processo geral de regulação da cidadania, ou de sua efetividade.

Como primeira aproximação ao problema, parece-me incontroverso que a ideia de que os que não têm profissão são pré-cidadãos, presente na formulação original de Wanderley Guilherme dos Santos, denota, a um só tempo, exclusão do mundo dos direitos e existência de mecanismos pelos quais, em algum momento, os pré-cidadãos podem ser incluídos, tornando-se membros plenos da comunidade de direitos. A exclusão, pois, pode ser temporária, isto é, a cidadania aparece, para esses pré-cidadãos, como possibilidade. Essa ideia está inscrita no conceito de "cidadania regulada": para Santos, Vargas delimitou cidadãos plenos, e também um conjunto de mecanismos que tornavam esse ambiente uma possibilidade talvez crível para os pré-cidadãos ${ }^{16}$, ou cidadãos em processo de vir a ser. Sustentarei aqui que mais do que uma possibilidade, a "cidadania regulada" era uma promessa, e que essa ideia capta com precisão parte substancial da dinâmica social brasileira no pós-1930, mais além, talvez, do que imaginou o mesmo Wanderley Guilherme dos Santos.

Para o trabalhador brasileiro típico, e muito particularmente o trabalhador que emigrou dos campos, aldeias e pequenas cidades do interior fugindo da pobreza ou em busca de melhores condições de vida, $\mathrm{o}$ acesso ao universo dos direitos do trabalho foi uma longa e muitas vezes frustrante corrida de obstáculos ${ }^{17}$. Para começar, os brasileiros quase nunca tinham registro civil. Parte dessa carência decorria das condições de vida de boa parte da população rural, quase sempre distante dos centros urbanos onde o registro era feito. Mas parte não desprezível tinha a ver com a resistência pura e simples, com origem na ideia nada irrealista de que o Estado era inimigo do povo, a quem tentava controlar, alistar no exército, escravizar, vacinar, higienizar ou simplesmente perseguir de maneira arbitrária ${ }^{18}$. Contudo, para obter uma carteira de trabalho ou qualquer outro documento, bem como para matricular os filhos na escola pública (que continuaria, por décadas, inca- 
paz de oferecer as vagas necessárias à educação da população) ou ter acesso a serviços de saúde (idem), o registro era obrigatório. Assim, obter a certidão de nascimento era o primeiro passo numa sempre difícil cruzada pelo acesso aos direitos, e ainda em 1948, já muito longe no processo de consolidação da "cidadania regulada", 23,4\% dos moradores de favelas no Rio de Janeiro não tinham esse documento (Fischer, 2008:124) ${ }^{19}$. Não há razão para imaginar que a situação fosse melhor nos demais grandes centros urbanos do país.

Obtido o registro civil, conseguir a carteira de trabalho, a "certidão de nascimento cívico" de W. G. dos Santos, exigia esforços adicionais. Como mostrou Fischer (2008), O trabalhador precisava prestar um conjunto completo de informações ao Departamento Nacional do Trabalho, incluindo estado civil, nível educacional, ocupação, endereço, nomes dos pais, além de levar uma fotografia. Ali, as impressões digitais eram registradas, e os demandantes precisavam informar os nomes, atividades e localização de seu empregador atual e dos antecessores, além de salários recebidos e data de admissão e demissão. Eram exigidos também os nomes, atividades e datas de nascimento de todos os dependentes, além dos sindicatos de que o trabalhador fosse eventualmente membro. Até aqui, tratava-se de informação, em princípio, simples de fornecer, não fosse o fato de que todas deviam ser provadas documentalmente, ou então por duas testemunhas portadoras de carteira de trabalho. Trabalhadores com vínculos precários de emprego, vida empregatícia errática (que não pudesse ser provada documentalmente) ou vida doméstica desviante (por exemplo, homem com parceira consensual ou mães solteiras) sabiam de antemão que o documento dificilmente seria emitido, e, sendo o caso, era pouco provável que os beneficiasse, isto é, que servisse de passaporte a um emprego formal, pois traria o registro do desvio pretérito. Mas havia mais. Se homem, o candidato precisava provar que estava em dia com o serviço militar. Candidatos analfabetos precisavam de três testemunhas, uma das quais disposta a assinar a papelada que compunha o prontuário do pedido do documento. De todos os candidatos exigiam-se diplomas ou cartas de empregadores provando suas habilidades profissionais, ou então, de novo, o testemunho de dois portadores de carteira de trabalho. Por fim, a carteira custava $\mathrm{Cr} \$ 5,00$ cruzeiros, um valor excessivo para desempregados e trabalhadores que recebiam um salário mínimo ou menos (ibidem:127 e ss.). A muitos essas exigências se afiguravam como verdadeiras barreiras à entrada no mundo dos direitos, aspecto recorrentemente lamentado por profissionais do serviço social públi- 
co, para quem as regras para obtenção da carteira eram "muito pesadas" para os mais pobres ${ }^{20}$.

Esse breve quadro impõe ao menos duas especificações importantes ao conceito de "cidadania regulada". Em primeiro lugar, como sugerido, o processo de instituição da legislação social gerou, por muito tempo, não uma divisão clara entre incluídos e excluídos, mas um continuum que fez da inclusão uma promessa mais ou menos distante segundo o lugar que o trabalhador ocupava na estrutura de distribuição de recursos monetários, bens, serviços, recompensas e, obviamente, direitos. Isso quer dizer que os direitos talvez aparecessem como "privilégio" dos que conseguiam cruzar o mar bravio da burocracia envolvida na obtenção dos documentos que habilitavam a um emprego formal, sem falar no próprio emprego. Mais do que isso, como havia meios de se chegar ao "privilégio", bastando para isso que o trabalhador seguisse normas que ao Estado pareciam formalmente impecáveis, como ter uma certidão de nascimento, ser bem casado e provar suas habilidades profissionais, a não obtenção do registro civil ou, depois, da carteira de trabalho era vista como fracasso pessoal, sobretudo porque outros (vizinhos, parentes ou amigos do fracassado) conseguiam. Não era o Estado que aparecia como impondo barreiras burocráticas a trabalhadores pobres e analfabetos. Estes é que não se apresentavam como estando à altura das normas do Estado enquanto artífice, segundo sua própria ideologia, de uma nova cidadania ali onde ela jamais existira.

Esse último aspecto não foi atentado por Fischer, em quem me baseio para sustentar a ideia do continuum de acesso a direitos. Ora, o trabalhador dos sonhos de Oliveira Vianna, Getúlio Vargas ou Marcondes Filho ${ }^{21}$ era o homem arrimo de família, alfabetizado, higienizado, saudável, senhor de uma profissão e titular de direitos sociais cuja origem seria sua vinculação a uma profissão regulamentada pelo Estado ${ }^{22}$. Esse homem, os três ideólogos sabiam muito bem, não existia, e, por isso, a tarefa da Revolução seria, justamente, forjá-lo. A "cidadania regulada" era um projeto para toda a nação, a ser, porém, estendido aos nacionais à medida que cada qual se qualificasse, ou se enquadrasse no ideal de pessoa que o Estado queria promover. Nesse sentido, o Estado não estava, de seu próprio ponto de vista, criando privilegiados. Estava acenando aos brasileiros que a segurança socioeconômica era acessível a qualquer um, desde que ele ou ela se pusesse à altura do que lhe estava sendo demandado e que, afinal, "era para seu próprio bem". E desde que, obviamente, houvesse emprego regulamentado para todos. 
Mas o emprego era apenas um dos múltiplos aspectos do projeto varguista de inclusão cidadã.

A segunda consequência desse arranjo para o conceito de "cidadania regulada" é que esta era em processo, e num sentido muito próprio do termo. Não apenas a ordem se apresentava aos brasileiros como um mundo possível, como ainda legitimava a luta por sua efetividade. Antes de 1930, a luta por direitos sociais e trabalhistas esbarrava na Constituição liberal de 1891. Qualquer medida que limitasse a liberdade de contrato entre pessoas livres e iguais era vista como inconstitucional, e a demanda por proteção do trabalhador, como simplesmente subversiva. Ou seja, a própria questão social era inconstitucional. Sob Vargas, ao contrário, os direitos estavam ali, completos, à mão dos que se dispusessem a se enquadrar nos requisitos definidos pelo Estado. O trabalhador já não precisava, como acontecera no modelo clássico de construção estatal, conforme analisado por Oliveira Vianna, lutar pelos direitos. Bastava a ele encontrar os meios para se titular aos benefícios sancionados, meios que o próprio Estado oferecia. E, muito importante, se ainda assim o empregador se negasse a seguir a lei, o trabalhador podia recorrer ao Estado para assegurar sua efetividade, por exemplo, via recurso à Justiça do Trabalho ou ao sindicato, também garantido pelo Estado.

Isso quer dizer que, malgrado o discurso apologético de justificação do regime varguista, a legislação trabalhista e social terminou por instaurar, no ambiente em que incidiu, um campo legítimo de disputa por sua própria faticidade, cuja matriz de legitimação era o próprio Estado. Com isso, o horizonte da luta por direitos tornou-se, legitimamente, o horizonte da luta de classes no país. A "cidadania regulada", nesse sentido, tornou-se a forma institucional da luta de classes entre nós: uma luta por efetividade dos direitos existentes; uma luta por extensão dos direitos a novas categorias profissionais; e uma luta por novos direitos. Isso quer dizer, ademais, que, se os direitos sociais e do trabalho (e os serviços sociais de saúde e educação) precisaram ganhar faticidade por meio da luta regulada de classes, então a "cidadania regulada" precisou ser conquistada pelos candidatos a ela, tanto individual quanto coletivamente. Tendo ou não sido outorgada por Vargas (discussão que tantas energias consumiu dos estudiosos do trabalho no Brasil $)^{23}, \mathrm{o}$ fato é que, no processo de tornar-se real no mundo, a legislação social foi apropriada pelos trabalhadores, e a "cidadania regulada" não era 
outra coisa senão o modo dessa apropriação em seu processo mais miúdo, mais cotidiano.

Revela-se, aqui, o sentido mais profundo da categoria de pré-cidadão, elemento necessário do conceito cunhado por Santos: no processo de instituição da legislação social, todos os trabalhadores eram, no ponto de partida, pré-cidadãos; à medida que se tornavam titulares de direitos aos poucos garantidos pelo Estado, deixavam apenas em parte aquela condição, já que precisavam lutar para vê-los ganhar efetividade em sua vida pessoal e coletiva. Essa luta, por fim, não estava aberta a todos da mesma maneira, e foi tal que não conseguiu nem universalizar os direitos, nem dar-lhes a faticidade pretendida por seus ideólogos e, depois, pelos próprios trabalhadores, organizados ou não.

\section{A PROMESSA E O BRASIL REAL}

Os limites à universalização da "cidadania regulada", de modo que esta incluísse todos aqueles que ela mesma definia como pré-cidadãos, eram portentosos e estavam muito além da capacidade de intervenção dos próprios trabalhadores. Antes de mostrar por que, cumpre reconhecer que parece paradoxal que a "cidadania regulada", definida como restrita a determinada parcela da população, se pudesse universalizar. Mas é da natureza do direito social e do trabalho delimitar titulares específicos de seus regulamentos ${ }^{24}$. Por exemplo, o seguro desemprego não faz sentido para proprietários dos meios de produção, crianças ou pessoas inativas. O descanso semanal remunerado idem. A aposentadoria, em todo o mundo, só muito tardiamente incluiu outros que não os trabalhadores assalariados ${ }^{25}$. Para que o conceito de "cidadania regulada" faça sentido, o problema relevante não é reconhecer que o direito social nunca é universal, no sentido de delimitar uma comunidade de titulares coextensiva à população como um todo, mas sim saber se ele está universalmente disponível ou é universalmente efetivo para as categorias populacionais que ele titula. É esse o significado do pré-cidadão da cidadania varguista: sua condição de trabalhador o tornava, imediatamente, potencial titular de direitos, mas para isso ele precisava se qualificar e conseguir um emprego regulamentado, como dissemos. O pré-cidadão é constitutivo do conceito de "cidadania regulada" porque, se todos os potenciais titulares do direito social se qualificassem, isto é, se todos deixassem de ser pré-cidadãos, então a cidadania já não seria regulada, e sim cidadania social sem mais, indistinta do conceito clássico de Marshall. Nossa cidadania era 
regulada porque, na maior parte do tempo, permaneceu como uma possibilidade, ou, mais propriamente, uma promessa de inclusão pela qual, sustento aqui, passou a valer a pena lutar.

Dito isso, a dinâmica social brasileira depois de 1930 foi tal que atualizou os piores temores de Vargas quanto aos riscos do êxodo rural para seu projeto de elevação moral, econômica e social do homem brasileiro. A extrema vulnerabilidade das condições de vida da maioria da população - estivesse ela lotada no mundo agrário, nos bairros rurais ou nas aldeias e pequenas cidades interioranas, nas periferias das grandes cidades ou em seu centro de gravidade -, tornava-a predisposta à busca de condições mínimas de sobrevivência em outra parte, sempre que a vida atual se lhe afigurasse insuportável, por qualquer motivo. A literatura sobre migrações no Brasil nunca se cansou de marcar que catástrofes naturais, a fome momentânea ou estrutural ou mesmo a desagregação rotineira ou violenta de formas tradicionais de vida não representaram motivos especiais para a migração das populações rurais $^{26}$. Quando muito, apressavam ou antecipavam movimentos que ocorreriam de qualquer modo. A mobilidade geográfica foi, sempre, característica dessa população vulneráve ${ }^{27}$, que tentou extrair seu sustento de um ambiente social caracterizado por grande restrição de aspirações, projetos e possibilidades reais, malgrado importantes diferenças regionais.

A partir de determinado momento no $V$ século brasileiro, o mundo urbano passou a exercer irresistível força gravitacional sobre essa população, gerando movimento avassalador de pessoas e famílias na direção das cidades em espaço muito curto de tempo. Isso também já foi muito estudado, mas é preciso dar uma ideia dos montantes envolvidos, para a correta compreensão do ponto em tela aqui. Ao longo da década de 1950 , deixaram o campo o equivalente a $24 \%$ da população rural contada no início da década. Isto é, um em cada quatro moradores do campo procurou as cidades naquela década. Nos anos 1960, saíram 36\% dos rurícolas existentes no início (mais de um em cada três pessoas), e, ao longo da década seguinte, nada menos que $42 \%$ (ou mais de dois em cada cinco) da população rural contada em 1970 (Merrick, 1986:62 ${ }^{28}$. Impossível argumentar, contrafactualmente, que os desgarrados do campo ou das vilas do interior do Brasil não teriam procurado as cidades se nestas o mercado de trabalho não tivesse sido ordenado e regulado, tornando-se atrativo e alimentando a utopia integradora dos direitos sociais e trabalhistas. A dificuldade com argu- 
mento dessa natureza está em que os milhões de pobres e miseráveis que habitaram o campo ao longo dos séculos fizeram-no porque era este o horizonte da vida de todos. Isto é, não havia alternativa para eles senão a escolha entre um chefe fazendeiro ou outro e, não havendo espaço aí, entre uma situação precária e miserável ou outra em algum lugar do imenso território brasileiro. É razoável imaginar que uma pessoa nessa situação teria preferido migrar para as cidades assim que nelas vislumbrasse uma saída para sua penúria, do mesmo modo que centenas de milhares deixaram o Nordeste em direção à Amazônia nos dois grandes ciclos da borracha, e assim como retornaram à sua região, também às centenas de milhares, em seguida ao esgotamento dos mesmos ciclos ou em resposta à melhoria das condições de vida em suas regiões de origem ${ }^{29}$. A atração pela cidade não diferiria da atração pelo Eldorado amazônico. A cidade seria, como argumentara Vargas, o lugar de "ilusórias facilidades".

Mas há fortes evidências em favor da atratividade dos direitos sociais. Iniciemos pelo lamento de um funcionário do Departamento Nacional de Imigração, que estudava casos de imigrantes que passaram pelo Serviço de Encaminhamento de Trabalhadores no Rio de Janeiro, em 1949. A força irresistível da cidade é por ele posta nesses termos: "No Nordeste, J. B. S., em atividade agrícola como jornaleiro, recebe dez cruzeiros por dia, de sol a sol, no eito. Do Rio, chega-lhe uma carta do compadre solteiro, revelando o seguinte: o ajudante de pedreiro [...] ganha 43 cruzeiros, trabalhando das 7 às 16 horas, com uma hora para almoço" ${ }^{30}$.

A carta do parente não tentava seduzir J. S. B. apenas pelo salário bem mais vantajoso. Mencionava também as horas de trabalho e de descanso, aspectos centrais da regulação do mercado de trabalho, e era o conjunto da informação que parecia configurar, para o burocrata ministerial, o que estou denominando "atratividade dos direitos".

As promessas de direitos sociais (muito especialmente o salário mínimo), além, é claro, de acesso a serviços públicos de educação e saúde, sempre valorizados pela população pobre, parecem ter atraído, além das populações desgarradas do campo, muitos daqueles antes submetidos aos padrões tradicionais de dominação - padrões que eram, ao mesmo tempo, veículos de segurança socioeconômica, ainda que subordinada - que, de outra maneira, talvez tivessem permanecido ali. Os direitos dos trabalhadores urbanos, nessa interpretação, estabele- 
ceram um parâmetro contra o qual os trabalhadores rurais passaram a julgar sua condição atual, mudando, com isso, e de maneira profunda, o patamar da aceitabilidade de sua tradicional penúria e subordinação ${ }^{31}$.

Na mesma direção, em 1973, em pesquisa junto a moradores de favelas em Campos do Jordão, Schühly (1981:97) constatou que apenas 18\% dentre 190 entrevistados tinham carteira de identidade. Porém, dos 195 trabalhadores da amostra, 82\% possuíam carteira profissional, embora apenas $61 \%$ tivessem um emprego registrado. Os pobres favelados preferiam a carteira profissional à de identidade, mesmo que a posse daquele documento não garantisse acesso ao mercado formal de trabalho, sendo, para muitos, apenas a insígnia de uma promessa. Do mesmo modo, dos 134 migrantes que responderam à pergunta sobre as razões para a migração, $42 \%$ mencionaram a busca de "melhores empregos", sendo que $48 \%$ tinham deixado sua cidade ou vila natal por "falta de empregos". Quanto da promessa de direitos estará escondido na busca por "melhores empregos" é difícil aquilatar. Mas parece plausível supor que essa motivação estivesse presente em boa parte dos trabalhadores que, em busca de melhores empregos, traziam consigo sua carteira profissional ${ }^{32}$.

Evidências esparsas como essa, mas não menos robustas, povoam a farta literatura sobre migrações do campo para a cidade no Brasil e sobre a consolidação do mundo urbano, estando muitas vezes invisíveis aos próprios pesquisadores. A esse respeito, voltemos ao trabalho de Lopes (1967:34). Ao analisar as motivações migratórias de operários fabris de duas pequenas cidades no interior de Minas Gerais, o autor aponta que "O meio urbano dessas comunidades, os seus maiores recursos, quer educacionais, quer médico-sanitários, ou, ainda, a segurança do trabalho, exercem perceptível atração sobre os trabalhadores rurais e pequenos sitiantes, cujos meios de subsistência na roça entram em crise" (ênfase minha).

Um pouco mais adiante, no mesmo parágrafo, Lopes afirma que "um [trabalhador] declara que veio com sua família 'para pagar instituto e dar educação aos filhos'", enquanto outros mencionam adicionais "motivos desta ordem". Ora, "pagar instituto" e outros "motivos desta ordem", no caso de operários fabris em 1957, ano da pesquisa de campo realizada por Lopes, queriam dizer a associação do trabalhador a um dos institutos de previdência oficiais. A atratividade da "cidadania 
regulada" passa virtualmente despercebida pela análise sempre fina do autor, e é secundada, na mesma fala, pela segunda promessa mais importante do desenvolvimentismo brasileiro, aquela relativa à educação dos filhos como meio de ascensão social. Do mesmo modo, e um pouco mais adiante, Lopes sustenta que os operários valorizam o emprego fabril vis-à-vis outras ocupações urbanas, "não só em função do salário, como também pela maior segurança que oferece (assistência médica, aposentadoria etc.)" (idem:51). Uma vez mais o "etc." revela a pouca importância atribuída na análise à promessa integradora dos direitos do trabalho, como o salário (naquele tempo, em geral, o salário mínimo) que, tudo indica, tinha centralidade nas motivações dos que buscaram as cidades ao longo das décadas.

Essas evidências sobre a adesão dos brasileiros à promessa integradora dos direitos sociais sugerem que, se, por um lado, o processo de inclusão dos nacionais no universo desses mesmos direitos foi desigual e intermitente, por outro, a crença na possibilidade de inclusão na "cidadania regulada" parece ter sido universal. Em 1976, os trabalhadores titulares de direitos, porque ocupantes de empregos registrados em carteira ou servidores públicos, eram 59\% da força de trabalho urbana no país. Contudo, tudo indica que a maioria dos trabalhadores, empregados ou não, ativos ou não, se havia titulado para o acesso a um emprego formal, caso ele aparecesse.

É o que sugere o Gráfico 1, que apresenta as curvas do crescimento da população economicamente ativa - PEA - urbana (ou trabalhadores de dez anos ou mais que estavam empregados ou procurando emprego), do número de carteiras de trabalho emitidas e do número de contribuintes para a previdência entre 1940 e 1976. A contribuição para a previdência, na ausência de indicadores mais precisos, funciona aqui como medida aproximada da proporção de trabalhadores lotados no segmento regulado da economia, aproximação, de resto, bastante acurada, pois até pelo menos 1971 o acesso à aposentadoria estava restrito a trabalhadores com carteira assinada e funcionários públicos ${ }^{33}$. Os valores no gráfico expressam o acréscimo de novos membros da PEA, titulares de carteiras e direitos previdenciários em cada período. Os montantes são portentosos. Em 1940, a PEA urbana era composta por pouco mais de 5 milhões de pessoas. Até ali, o Ministério do Trabalho emitira menos de 1 milhão de carteiras de trabalho, e os contribuintes para a previdência eram pouco menos de 2 milhões de pessoas, ou perto de $38 \%$ dos ocupados. Logo, o trabalho regulado e protegido pela le- 
gislação social e trabalhista não atingia $40 \%$ dos ocupados nas cidades $^{34}$. Entre 1940 e 1950, a PEA urbana seria acrescida de 1,8 milhão de pessoas, enquanto aos contribuintes para a previdência somaram-se menos de 1,2 milhão de trabalhadores. Entretanto, o Ministério do Trabalho emitiu 2,7 milhões de carteiras de trabalho no mesmo período. $\mathrm{Ou}$ seja, foram emitidas $150 \%$ mais carteiras do que o crescimento da PEA, e $230 \%$ mais do que beneficiários da previdência social. Isso parece indicação bastante forte de que os trabalhadores acreditavam na possibilidade de sua incorporação pelo mercado formal em consolidação, já que se habilitaram para isso (isto é, tiraram sua carteira de trabalho) em proporção muito superior à própria oferta de postos de trabalho (aqui mensurada pela PEA urbana). Mais do que isso, a titulação foi muito superior à capacidade de regulação pelo sistema previdenciário, isto é, à capacidade de incorporação dos novos citadinos pelo mundo dos direitos sociais e do trabalho, e isso num ambiente de enormes restrições burocráticas à titulação. Ao que parece, a crença na promessa dos direitos deve figurar entre as explicações para a habilitação sempre muito superior à disponibilidade desses mesmos direitos por parte dos trabalhadores que migravam do campo para a cidade.

Essa dinâmica se aceleraria nas décadas seguintes. Entre 1950 e 1960, seriam emitidas $36 \%$ mais carteiras do que o crescimento da PEA urbana, e nada menos do que $377 \%$ mais do que o crescimento no número de contribuintes previdenciários. Entre 1960 e 1970, as carteiras emitidas superaram o crescimento da PEA urbana em 213\%, e em 271\% nos seis anos posteriores (até 1976). No período considerado aqui (1940-1976), foram titulados com a carteira de trabalho 2,78 vezes mais brasileiros do que aqueles efetivamente acolhidos pelo sistema previdenciário, e 1,92 vezes mais do que os que figuraram na própria $P A^{35}$. Isso quer dizer que o crescimento de contribuintes à previdência social correspondeu a apenas $38 \%$ do aumento dos que se titularam com a carteira de trabalho no período. Nesse quadro, aquele primeiro valor (2,78 vezes) deve ser tomado como a medida mesma da inflação da crença dos trabalhadores brasileiros na promessa dos direitos, que gerou uma esperança de inclusão quase três vezes superior às possibilidades reais do mercado formal de trabalho urbano ao longo de mais de três décadas. Lendo os mesmos números de outra maneira, pode-se dizer que a taxa objetiva de desconto das esperanças de proteção social foi de $62 \%$, proporção de titulares de carteiras de trabalho que excedeu à de contribuintes previdenciários ao longo dos anos, atualizando, assim, 
Uma Utopia Brasileira: Vargas e a Construção do Estado de Bem-Estar...

\section{Gráfico 1}

Evolução da PEA Urbana, do Número de Carteiras de Trabalho Expedidas pelo Ministério do Trabalho e do Número de Contribuintes para a Previdência Social: Brasil, 1940-1976

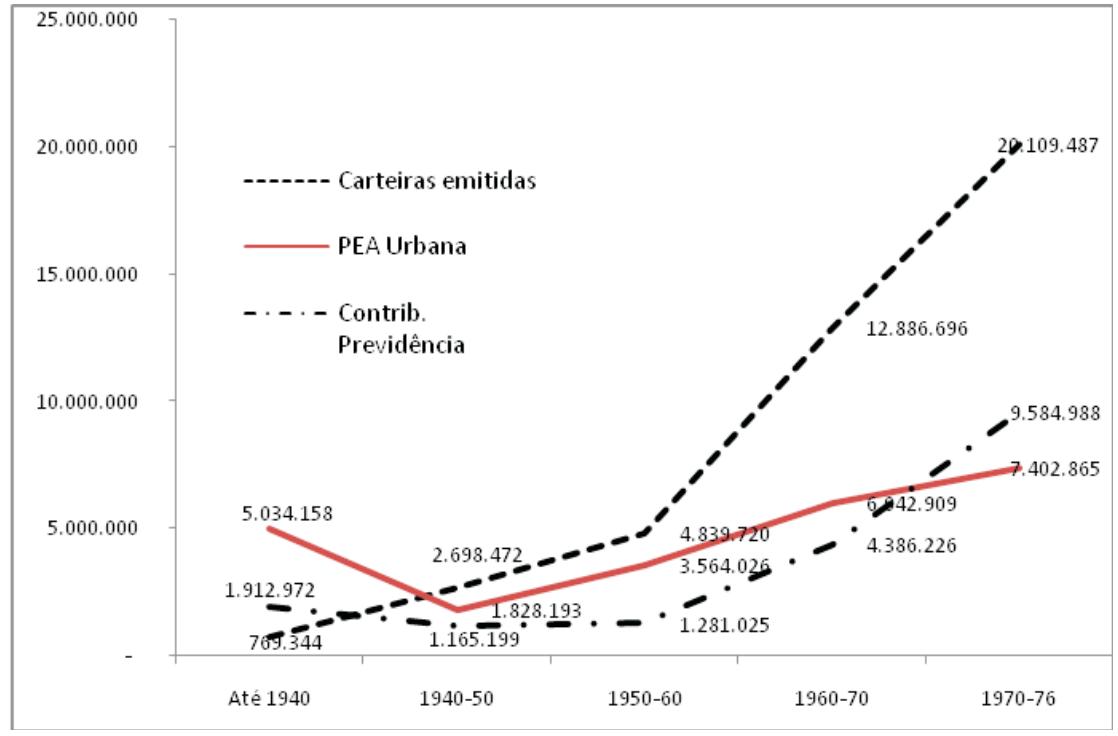

Fontes: Anuário Estatístico do Brasil (IBGE, vários anos); e IPEADATA para estimativas daPEA urbana e dos contribuintes para a previdência social. Os dados foram cotejados com os de IBGE (2003) e podem apresentar pequenas diferenças, que não influem no movimento geral.

os piores temores de Vargas quanto aos riscos que a migração rural/urbana representava para seu projeto civilizatório.

Cabe notar que, se as promessas de proteção sofreram substancial taxa de desconto pelos fatos, parece incontestável que o emprego registrado no Brasil representou, para parcelas crescentes dos trabalhadores urbanos (e, tudo indica, também para parte dos trabalhadores rurais ${ }^{36}$ ), um ponto de referência normativo para a estruturação das expectativas individuais e coletivas quanto aos padrões do que se poderia denominar "mínimos civilizatórios", aquém dos quais o mercado de trabalho não poderia operar de forma legítima. Salário mínimo, direito a férias regulares, descanso semanal remunerado, abono de natal (igual ou próximo ao salário percebido) etc. tornaram-se parâmetros que passaram a operar, também, em segmentos do mercado assalariado informal, no âmbito de acordos tácitos entre empregadores informais e assalariados sem carteira, que tomavam esses direitos como justos. Mesmo que nunca se tenha universalizado, o mercado formal estruturava 
um conjunto de relações sociais e econômicas que ocorriam ao seu largo, pela razão mesma de que os assalariados urbanos esperavam, cedo ou tarde, integrar-se a ele. E essa expectativa era de fato atendida vez por outra no curso da vida empregatícia de homens e mulheres, em razão das sempre muito altas taxas de rotatividade da economia urbana brasileira, sobretudo nas ocupações menos qualificadas ${ }^{37}$.

São extraordinárias, a esse propósito, algumas trajetórias ocupacionais de migrantes sumariadas por Lopes em outro estudo fundador (1971:41): um trabalhador foi operário por um ano e meio, retornou a seu sítio por 21 dias, foi vendedor em porta de loja por um ano e novamente operário por quatro anos; outro foi lavador em empresa de ônibus por três meses, operário por oito anos, trabalhou em sítio por dois anos, outra vez operário por dois meses e de novo operário por mais dois anos; um terceiro foi servente de pedreiro por dois meses, aprendiz de padeiro por duas semanas, operário por um ano e meio, vendedor na base de comissão por tempo não informado, operário por 15 dias e novamente operário por dois anos e meio. Essas trajetórias erráticas são a expressão mais cabal da insegurança socioeconômica de trabalhadores urbanos pouco qualificados, sujeitos a dinâmicas de mercado inteiramente fora de seu controle, já que a carência de especialização de qualquer tipo reduzia seu poder de barganha num mercado hipersaturado ${ }^{38}$. Mas o que importa marcar aqui é que o trânsito regular, ainda que efêmero, por um emprego formal e protegido terminava gerando expectativas de retribuição equivalente no mercado assalariado informal, e estas eram por vezes atendidas ${ }^{39}$. E, ao que tudo indica, os trabalhadores acreditavam que o mercado formal os acolheria novamente em algum momento de sua vida empregatícia ${ }^{40}$.

\section{A PROMESSA E A DESIGUALDADE}

Apesar da adesão dos trabalhadores à utopia varguista, e de sua luta por dar faticidade à "cidadania regulada", as recompensas a ela associadas foram, quase sempre, insuficientes para assegurar a "valorização integral do homem brasileiro". Tomemos, apenas como exemplo, a fixação do salário mínimo, propagandeado pelo Estado Novo como um dos principais instrumentos dessa valorização. Como também já fartamente estudado, aquele salário foi definido pelo Decreto-Lei no 399, de 1938, como "a remuneração mínima devida a todo trabalhador adulto, sem distinção de sexo, por dia normal de serviço, e capaz de satisfazer, em determinada época e região do país, às suas necessidades normais 
de alimentação, habitação, vestuário, higiene e transporte". Esse texto seria mais tarde incorporado à CLT e aprimorado pela Constituição de 1946, que incluiria as necessidades do trabalhador e de sua família.

O Decreto-Lei no 2.162, que definiu o primeiro valor do salário mínimo em maio de 1940 com base em estudos regionais específicos realizados ao longo de 1938 e 1939, estabeleceu-o em 240 mil réis para o Distrito Federal (cidade do Rio de Janeiro). Esse foi o maior valor arbitrado no país. São Paulo foi contemplado com 220,6 mil réis, enquanto em certas regiões interioranas do Norte e do Nordeste o valor não ultrapassou os 90 mil réis $^{41}$. Esse último montante equivalia, em 1939, a menos de $70 \%$ do gasto mensal com alimentação de um só membro de uma família de classe média no Rio de Janeiro ${ }^{42}$. Isso quer dizer que o salário mínimo de 240 mil réis dava para alimentar 2,6 membros da mesma família por mês e nada mais ${ }^{43}$. O simples aluguel de uma casa para essa família, por sua vez, requeria 2,6 salários mínimos. É claro que a renda mínima não se destinava a famílias de classe média, que gastavam apenas com criados, em 1939, 200 mil réis em média. Mas essa constatação dá a medida do poder de compra da renda arbitrada por Vargas e divulgada com grande alarde nas comemorações do Primeiro de Maio de 1938. Dá uma medida, também, da tolerância com a desigualdade social embutida na legislação do salário mínimo: aquela família de classe média carioca gastou por mês, em média, em 1939, nada menos do que 10 vezes o mínimo arbitrado em $1940^{44}$. Se considerarmos que mulheres de classe média raramente trabalhavam, e que, portanto, esse gasto, muito provavelmente, era assumido pelo chefe da casa, então o ganho mensal de um profissional de classe média era provavelmente muito superior a 10 vezes o salário mínimo em 1940 (considerando os gastos correntes e alguma poupança).

Definido em patamar muito baixo, o valor nominal do salário mínimo permaneceu, ademais, congelado entre julho de 1940 e maio de 1943, o que representou perda real de poder de compra de perto de $40 \%$, inflação acumulada no período. Os $25 \%$ de reajuste concedidos por Vargas em maio de 1943 não repuseram as perdas, que foram compensadas em dezembro do mesmo ano com mais $27 \%$ de reajuste, contra inflação adicional de $12 \%{ }^{45}$. Todavia, embora a legislação comandasse revisão trienal de seu valor, a partir de janeiro de 1944 e até dezembro de 1951, portanto já no novo governo Vargas, não haveria novos reajustes, e o salário mínimo, corroído pela inflação, atingiu seu valor mais baixo em muitas décadas, equivalente a $40 \%$ da cifra do início do período ${ }^{46}$. 
Ainda assim, para determinados setores da economia urbana, a fixação do salário mínimo pode ter representado ganhos de renda, obviamente condicionais à sua efetiva adoção pelos empregadores, algo sempre problemático num Estado que contou, historicamente, com parcos recursos para fiscalizar a vigência da legislação trabalhista ${ }^{47}$. De qualquer modo, há indícios de que, com o passar do tempo, o valor depreciado do mínimo tornou-se referência, não como remuneração mínima, mas como teto para grande parte das ocupações assalariadas urbanas, inclusive na indústria.

Com efeito, em 1939, o salário médio mensal pago a um operário industrial foi de 177 mil réis ${ }^{48}$. Nas indústrias modernas, o valor foi mais alto: 238,4 mil na metalurgia; 284,4 mil na mecânica; e 300,9 mil na de material de transporte, indústrias concentradas no eixo Rio/São Paulo. No ano seguinte, o salário mínimo foi decretado acima de 177 mil réis justamente para os estados de São Paulo (220 mil), Distrito Federal (240 mil), além de Rio de Janeiro e Rio Grande do Sul (200 mil) e Bahia e Paraná (180 mil), conforme Montali (s. d.:2). Para uma parte da indústria, pois, o mínimo excedeu o salário médio efetivamente pago em 1939, mas não nos setores emergentes e mais dinâmicos ${ }^{49}$. Estes continuaram "descolados" da remuneração arbitrada ainda por algum tempo. Mas o descolamento, contrariamente ao que se deveria esperar em setores de mão de obra mais especializada e escassa, não se deu na direção de remunerações mais altas.

Assim, em dezembro de 1943, o salário mínimo foi arbitrado em Cr\$ 360 no Distrito Federal e em Cr\$340 em São Paulo (o mil-réis havia deixado de existir em 1942). O salário médio pago na indústria nessas duas localidades em julho daquele mesmo ano fora de Cr\$ 417 e Cr\$354, respectivamente, logo, superior ao salário mínimo praticado até ali, congelado desde 1940 em Cr\$240 e Cr\$220. O novo valor mínimo, pois, se aproximou do que a indústria efetivamente já praticava em termos médios, e pode ter forçado um ajuste dos menores salários em direção ao novo preço arbitrado nessas duas regiões, o que, contudo, é difícil demonstrar com as evidências disponíveis ${ }^{50}$. Ainda assim, é muito pouco provável que esse ajuste tenha ocorrido nos demais estados da federação, já que em todos eles os operários recebiam, em média, em dezembro de 1943, menos do que o Estado arbitrara como o salário de subsistência, por sua vez definido em patamar muito abaixo das necessidades reais de uma família operária típica ${ }^{51}$. 
Vargas não daria novos reajustes ao mínimo no Estado Novo, e o governo Dutra simplesmente não aplicou a legislação que obrigava à revisão trienal de seu preço (prevista para dezembro de 1946). Com isso, entre 1944 e 1951, quando a inflação superou os 182\%52, configurou-se o maior arrocho imposto ao salário base até ali e por algumas décadas posteriores. A consequência foi novo descolamento da remuneração média dos operários fabris do valor artificialmente arbitrado em patamar muito baixo, como, aliás, era intenção do governo Dutra, que tentava anular o papel do salário mínimo na regulação da economia ${ }^{53}$. Em 1949, um operário médio recebeu Cr\$ 835 por mês, para um salário mínimo congelado em Cr\$360 no Distrito Federa ${ }^{54}$. Os trabalhadores industriais parecem ter conseguido, apesar da enorme repressão e da intervenção em quase todos os sindicatos identificados com Vargas ou dominados pelos comunistas ${ }^{55}$, repor ao menos parte das perdas inflacionárias do período ${ }^{56}$. Mas em 1959, depois de nova política de recuperação iniciada no segundo governo Vargas e levada adiante por Juscelino Kubitschek, o mínimo foi novamente arbitrado em consonância com o salário médio pago a um trabalhador de produção, que era de Cr\$ 6.000. Uma vez mais, parte substancial dos trabalhadores industriais recebia abaixo do mínimo legal, e uma vez mais os salários gerais parecem ter convergido apenas parcialmente para aquele patamar, configurando o já mencionado "efeito farol" desse preço arbitrado como teto de boa parte das remunerações.

Assim, em 1960, nada menos do que 56\% dos trabalhadores urbanos ganhavam até um salário mínimo ${ }^{57}$. Desagregando esse valor pelos ramos industriais, descobre-se que $83 \%$ dos empregados na indústria de transformação, 91\% dos operários da construção civil e 95\% daqueles lotados em indústrias extrativas encontravam-se nessa faixa de renda, ou seja, igual ou inferior ao mínimo ${ }^{58}$. Em 1966, quando o salário mínimo valia 36\% menos do que em 1959, a remuneração na indústria se havia descolado novamente, mas apenas em parte: $46 \%$ dos operários paulistas que tinham carteira assinada, $49 \%$ dos cariocas, 70,5\% dos pernambucanos, $70 \%$ dos mineiros (para média de $53 \%$ dos brasileiros) recebiam até um salário mínimo. Considerando até dois mínimos, tínhamos $78 \%$ dos trabalhadores formais urbanos ${ }^{59}$. Como afirmou Oliveira (1981), em análise clássica, "o leque da remuneração dos trabalhadores urbanos não é um leque, mas um pobre galho com apenas dois ramos", os que ganham até um salário mínimo e os poucos que ganham mais do que isso (ibidem). E o autor acrescentaria: 
A fixação dos demais salários, acima do mínimo, se faz sempre tomando a este como ponto de referência e nunca tomando a produtividade de cada ramo industrial ou de cada setor como parâmetro que, contraposto à escassez específica, servisse para determinar o preço da força de trabalho. A institucionalização do salário mínimo faz concreta, ao nível de cada empresa, a mediação global que o mesmo desempenha ao nível da economia como um todo: nenhuma empresa necessita determinar o preço de oferta da força de trabalho específica do seu ramo, pois tal preço é determinado para o conjunto do sistema (p. 54).

A arbitragem do salário mínimo em patamares quase sempre muito baixos teve impactos na distribuição de renda no país, ao aprofundar, no tempo, as distâncias sociais entre os muito ricos e os muito pobres. Em 1960, os 10\% mais ricos se apropriavam de 39,6\% da renda nacional. Em 1970,46,7\%; e 51\% em $1980^{60}$. Esse resultado dificilmente pode ser atribuído unicamente ao salário mínimo, mas já não há controvérsia sobre o fato de que - sobretudo durante os governos militares, quando aquele preço arbitrado foi novamente depreciado, num momento em que o Estado voltou a controlar os sindicatos e a definir políticas oficiais de reajuste salarial - o "efeito farol" do mínimo vigorou com toda força, no sentido de comprimir os salários dos segmentos mais dinâmicos, ou, ao menos, de impedir que eles fossem definidos pelo que Oliveira denominou "escassez específica" de força de trabalho.

\section{PALAVRA FINAL}

É fato que o salário mínimo foi, quase sempre, simples promessa de renda de subsistência. Em boa parte de sua história, esteve abaixo desse nível, e a maioria dos trabalhadores era, por sua vez, remunerada abaixo do valor arbitrado pelo Estado. Mas isso não anulou seu aspecto civilizatório, na medida em que aos trabalhadores foi sinalizado que uma renda digna era direito seu, e, portanto, era o caso de se lutar por ela, mesmo que, por injunções políticas ou econômicas, o Estado se abstivesse de manter o poder de compra do salário que unilateralmente determinava. Isso vale para esse preço arbitrado, os serviços de saúde e educação, o valor das aposentadorias e tudo o mais que a obra de "valorização do homem brasileiro" tornara um direito, legitimando, com isso, a luta por dar-lhe faticidade.

Mesmo que, para boa parte dos brasileiros, o mundo dos direitos construído ao longo da Era Vargas tenha permanecido uma promessa - pois 
até pelo menos o final da década de 1960 nunca menos de $50 \%$ dos trabalhadores urbanos tinham vínculos empregatícios extrínsecos à legislação trabalhista -, o que importa para a discussão em tela é a ideia de que aquele mundo passou a fazer parte inarredável do horizonte de expectativas das populações que viviam do trabalho como a insígnia mesma da "boa vida", medida contra um parâmetro de grande e multidimensional vulnerabilidade e insegurança socioeconômica: a vida no campo. Para boa parte das massas rurais e urbanas, cuja vida cotidiana e cujos processos de diferenciação eram espontâneos, miúdos, instáveis, em grande medida invisíveis ao Estado ou ao capital, o mundo dos direitos sociais e do trabalho, ou a "cidadania regulada", ofereceu um referencial poderoso para a construção de suas identidades individuais e coletivas. Agora, o horizonte das aspirações já não estava demarcado pela penúria de todos, e sim pelo sonho da autopromoção pessoal pela via do trabalho protegido pelo Estado.

Dizendo de outro modo, durante a maior parte da história recente do Brasil, o sentimento de privação relativa, de tão importantes consequências para a dinâmica social em sociedades desiguais em processo de acelerada mudança ${ }^{61}$, não encontrou terreno fértil, porque os estilos de vida de dominantes e dominados eram incomensuráveis, e aos dominados parecia impensável aspirar à posição dos poderosos, simplesmente porque ela estava longe demais. A "cidadania regulada", ao contrário, estava ao alcance de todos, desde que cada qual se habilitasse a ela. Isso estabeleceu uma distinção irresistível entre brasileiros do campo e da cidade, tornando a cidade um destino também irresistível, porque lugar de atualização da "crença utópica" (Touraine, 1961) na inclusão pelos direitos sociais. Essa foi uma das razões do fracasso do projeto varguista, e aqui é preciso insistir. Não importa se esse projeto era "para valer" ou se parte da elite dirigente entorno a Vargas via nele apenas um meio de controle das massas ou de sustentação de seu próprio projeto de poder ${ }^{62}$. É provável que motivações dessa natureza animassem muita gente. No entanto, do ponto de vista que interessa ao argumento aqui defendido, o que importa é que, uma vez instituída, a legislação social tornou-se objeto real de aspiração das massas despossuídas de recursos e direitos, simplesmente porque foi apresentada como, justamente, um conjunto de direitos, e não como privilégios. A literatura mais recente sobre o tema tem parcialmente razão em sustentar que, a muitos trabalhadores, aqueles que conseguiram se titular para ascender ao mundo da "cidadania regulada" pareciam privilegia- 
$\operatorname{dos}^{63}$. Mas como essa posição estava acessível, idealmente, a qualquer um que conseguisse sua carteira de trabalho, o privilégio se transformava, imediatamente, em aspiração legítima, e o acesso àquela posição, em uma conquista, agora em ambiente regido pelo direito, não pelo privilégio. E isso apesar da via crucis que podia se tornar o trâmite pela burocracia estatal para a obtenção dos documentos de acesso aos direitos. É toda uma nova concepção de Estado que está em jogo aqui. Até Vargas, a questão social era inconstitucional, e o rosto do Estado para os nacionais era a polícia. É claro que French (2004) tem razão ao afirmar que Vargas foi tão ou mais violento em relação ao trabalho organizado do que Washington Luis ou Arthur Bernardes. A questão social, sempre que emergiu por fora da "cidadania regulada" (por exemplo, na forma do proselitismo comunista ou socialista, ou da luta por um sindicalismo autônomo), foi combatida de forma sangrenta depois de $1935^{64}$. Mas ao apresentar-se diante dos nacionais como um projeto, como uma ordem jurídica carente ainda de faticidade, o Estado varguista afirmou-se como o Estado de sua nação, e não como uma instituição a serviço dos poderosos. Vargas (e aqui eu o tomo como personificação de um projeto de construção estatal) enunciou, diante de uma nação até ali em grande medida alheia a seu Estado, que havia um projeto em curso de construção nacional e que nele havia lugar para os trabalhadores. Ademais, e ao menos no discurso apologético da ordem, um lugar de destaque. Isso representou novidade completa na história brasileira até ali, uma história em que o Estado fora construído contra o inimigo interno representado pelo povo miserável, mestiço, perigoso. Verdade ou não, ideologia ou não, o fato é que isso fez da faticidade da ordem em construção um interesse daqueles a quem a ordem dizia querer incluir, e, a partir de então, lutar pela vigência dos direitos sociais tornou-se aspecto central do processo pelo qual o Estado ganhou efetividade no Brasil. Com Vargas, os trabalhadores ganharam um centro de identificação de caráter geral e, muito importante, no interior e nos limites da ordem capitalista que o Estado varguista também tentava transformar. A partir de então, qualquer projeto de superação da penúria a que os trabalhadores continuaram submetidos pelas décadas seguintes ao primeiro período Vargas precisou competir com essa sólida aspiração dos trabalhadores por inclusão na chave dos direitos sociais $^{65}$. A consciência de classe dos trabalhadores brasileiros foi, por muito tempo, a consciência do direito a seus direitos, cuja efetividade esteve sempre em processo e, nesse sentido, foi, sempre e renovadamente, utópica. 
Aspecto também pouco atentado pela literatura corrente sobre o tema tem a ver com o fato de que Vargas iniciou o processo (certamente ainda inconcluso) de civilização do capital, ao impor-lhe trabalhadores não como corpos dos quais os capitalistas se desfaziam com a sem-cerimônia dos senhores de escravos, mas como pessoas em relação às quais tinham obrigações definidas em lei. O Estado varguista impôs à elite, em grande medida indiferente, massas trabalhadoras dotadas de humanidade, e, portanto, dignas de ser reconhecidas em sua individualidade, autonomia e liberdade. Mesmo que o empresariado brasileiro tenha resistido profundamente a dar efetividade à regulação do mundo do trabalho, perdeu para sempre a prerrogativa da indiferença. Depois de 1945, esta seria substituída pela desconfiança, pelo medo e pelo preconceito de classe, mas a indiferença substantiva em relação ao destino das massas, fruto de seu não reconhecimento como "outro" digno de um "eu" autorreferente, já não tinha espaço na sociabilidade em mutação.

Tudo isso se deu, repita-se, à custa da restrição das aspirações e dos projetos de parte importante dos trabalhadores. O trabalho organizado teve, em Vargas, a afirmação de seu direito à construção de identidade, mas se, e somente se, essa construção ocorresse no âmbito da "cidadania regulada". Vargas enquadrou, pela violência física e simbóli$\mathrm{ca}$, o horizonte de expectativas e a vida cotidiana dos trabalhadores, limitando-os às fronteiras mesquinhas da sociabilidade capitalista, ao prometer acesso ao mundo do consumo e aos bens da civilização liberal, muito especialmente os direitos sociais que o liberalismo renovado do século XX incorporou em sua matriz regulatória. Os símbolos da identidade operária passaram a ser o "operário padrão", o "pai dos pobres" e a CLT. Porém, apesar de mesquinhas, aquelas fronteiras deram significado real à vida da maioria, e razões para lutar por sua efetividade. Até pelo menos a década de 1980, nenhuma força política articulada posteriormente à morte de Vargas foi capaz de opor projetos alternativos viáveis de construção identitária para as populações que vivem do trabalho ${ }^{66}$.

O projeto varguista de inclusão pelo direito social revelou-se, por fim, poderoso instrumento de reprodução das desigualdades sociais no Brasil. A imensa onda migratória, montante a partir dos anos 1940, gerou longeva inércia social no processo de inclusão dos migrantes no mundo do trabalho, restringindo de maneira importante, como foi dito, a efetividade da promessa varguista. Mas o efeito demonstração 
das não poucas trajetórias individuais ascendentes mostrou aos brasileiros que, embora difíceis de se alcançar, as promessas da integração ao mundo dos direitos e de acesso às benesses civilizatórias à brasileira eram não apenas críveis, mas possíveis a quem fizesse por isso. Isso gerou um processo retroalimentado de legitimação da ordem desigual, de grande alcance para a sustentação de sua estrutura mais geral, malgrado os enormes custos sociais e pessoais da permanência da desigualdade.

(Recebido para publicação em fevereiro de 2010)

(Reapresentado em julho de 2010)

(Versão definitiva em novembro de 2010)

\section{NOTAS}

1. O índice de Gini é a medida mais comumente usada para expressar a apropriação da renda por uma população específica. Varia de 0 a 1 , e um índice 0 quer dizer que cada pessoa na população se apropria da mesma renda que cada outra pessoa. Um índice 1 significa que uma única pessoa se apropria de toda a renda disponível. Logo, quanto mais próximo de 1, mais concentrada é a distribuição total da renda numa dada população. Já foi demonstrado que, em países com alta concentração de renda, o Gini não é a melhor medida, por não ser sensível aos extremos da distribuição. Além disso, o índice é medida bastante restrita da desigualdade, já que esta se expressa em múltiplas dimensões além da renda. O objetivo aqui é apenas mostrar que esta sempre foi muito concentrada em nosso país, e que o padrão de concentração é persistente no tempo.

2. Os índices de 1872 e 1920 foram estimados por Bértola et alii. (2009) em estudo ainda preliminar, de modo que os valores devem ser tomados com cautela. Os de 1976 e 2006 estão disponíveis em http:/ / www.ipeadata.gov.br e são fidedignos (acessado em setembro de 2009).

3. Nesta análise, utilizo a versão do texto publicada em Lopes (1971:22-95). As citações trarão apenas o número da página.

4. As páginas se referem à edição original, Touraine (1961).

5. Muito especialmente, Martins Rodrigues (1966 e 1970).

6. Ver também Paoli et alli. (1983), além de Gomes (1988).

7. Em Populações Meridionais do Brasil, Oliveira Vianna vê na luta de classes um poderoso agente de solidariedade social, muito "eficiente na organização dos povos ocidentais" (p. 157). Fazendo eco a Marx, afirma que “Toda a evolução grega, toda a evolução romana, toda a evolução medieval, toda a evolução moderna se fazem sob a in- 
fluência fecunda da luta de classes. Em nossa história, tais conflitos são raríssimos [...]. Duram tempo brevíssimo. Desdobram-se em áreas restritíssimas", não sendo, portanto, promotores da solidariedade, trazendo, ao contrário, efeitos negativos "à evolução política e social da nacionalidade" (pp. 157-158).

8. Numa amostra de que isso talvez fosse mesmo possível, em 1943 o Japão invadiu a Malásia, para onde as sementes da seringueira amazônica haviam sido pirateadas no final do século XIX, o que liquidara o monopólio brasileiro na produção do látex. A invasão japonesa provocou súbita carência da matéria prima, e os seringais da Amazônia, praticamente desativados desde inícios do século $\mathrm{XX}$, voltaram à ativa pelas mãos dos "soldados da borracha", migrantes, nordestinos em sua maioria, que atenderam ao chamado do Estado para a produção de borracha nas florestas do Acre e do Amazonas, como parte do esforço de guerra do Brasil. Ver Silva (1982).

9. Em 1939, portanto dois anos antes desse discurso, duas culturas, café e algodão, tinham respondido por nada menos que $60 \%$ do valor global das exportações do país (IBGE, 1941:90). Além de medida importante da fragilidade do comércio exterior, essa cifra revela a enorme dependência da nação em relação a um punhado de grandes produtores de café e algodão, bem como a dificuldade de Vargas confrontar diretamente seus interesses. Vale lembrar que, em seu discurso de posse na chefia do governo provisório, em 3 de novembro de 1930, ele enumeraria entre as tarefas do governo revolucionário "promover, sem violência, a extinção progressiva do latifúndio e, assim, proteger a organização da pequena propriedade" e estimular o trabalhador a "construir com as próprias mãos, em terra própria, o edifício de sua prosperidade" (1938, vol. 1:73). Em 1941, essa tarefa era ainda uma promessa e assim permaneceria pelas décadas seguintes.

10. Calculado a partir de IBGE (1941:120), com dados para a receita per capita, deflacionada pelo valor da libra esterlina em mil réis (apresentado na mesma publicação, p. 64 , tabela 2).

11. Como mostraram Tavares de Almeida (1978) e Gomes (1979).

12. Eram 273 mil operários em São Paulo, segundo Dean (1971:127), numa população economicamente ativa estimada em $55 \%$ dos 1,3 milhão de habitantes.

13. Os números são aproximados, porque os dados publicados dos censos incluíram inativos e atividades mal definidas numa mesma categoria. Ver IBGE (2003) para os dados de população.

14. É sabido que boa parte da obra legislativa de Vargas estivera antes nas reivindicações do movimento operário anterior a 1930, como demonstrou pioneiramente Moraes Filho (1952), pondo por terra o mito da dádiva ou outorga dos direitos trabalhistas por Vargas. Isso levou Gomes (1988) a sugerir que a fala operária teria sido apropriada por Vargas e transformada em mecanismo de controle sobre os próprios operários. Mais adiante veremos que, conquanto relevante, a discussão sobre o mito da dádiva é lateral ao argumento central deste artigo.

15. Alguns trabalhos de referência obrigatória são Simão (1966), Dean (1971), Werneck Vianna (1999), Tavares de Almeida (1978), Santos (1979), Erickson (1979), Gomes (1979 e 1988), French (2004) e Fischer (2008). A divergência de conteúdo, quando ocorre, refere-se, em geral, aos institutos que este ou aquele autor inclui (ou deixa de lado) na configuração legal de proteção social varguista. 
16. O conceito, pois, difere da noção de subcidadania, que recobre o que Souza (2000) denomina ralé permanentemente excluída por nosso processo de "modernização seletiva". O argumento aqui defendido é oposto pelo vértice a essa ideia simplificadora.

17. Mostrar isso em detalhes para o caso dos pobres do Rio de Janeiro é uma das grandes contribuições de Brodwyn Fischer (2008) à compreensão da construção da sociedade do trabalho no Brasil, ainda que sua pesquisa tenha foco exclusivo nesse estado. A frágil faticidade do direito do trabalho é sistematicamente investigada também por French (2004), embora, como veremos mais adiante, eu considere incompleta sua compreensão daquela faticidade.

18. As populações do século XIX e inícios do XX tinham razões de sobra para desconfiar das tentativas de ingerência do Estado em suas vidas cotidianas. Revoltas como as da Cumbuca, contra a lei do sorteio militar obrigatório, de 1874, ou a da Vacina, no Rio de Janeiro, em 1904, tiveram como motivo principal a percepção de que o Estado estava indo longe demais em sua tentativa de ordenar a vida dos mais pobres. Essa ideia explica a resistência, também, ao recenseamento e à cobrança de impostos nas comunidades rurais, e às políticas de saneamento sanitário nas cidades. Para o recenseamento e os impostos, ver Queiroz (1965:216). Analiso as medidas sanitárias em Cardoso (2010).

19. Em Rios e Mattos (2005) encontramos vários depoimentos de descendentes de ex-escravos que tampouco tinham registro formal de nascimento. A carência era comum também em comunidades quilombolas (Gomes, 2006) e em comunidades de migrantes nordestinos nas cidades do sudeste (Perlman, 1977; Durham, 1973).

20. Boletim do SOS citado por Fischer (2008:129).

21. Alexandre Marcondes Filho, Ministro do Trabalho nos últimos anos do Estado Novo, foi um dos grandes responsáveis pela consolidação do mito da dádiva dos direitos por Vargas, com sua fala radiofônica semanal de dez minutos, na Hora do Brasil. As mais de duzentas palestras proferidas entre 1942 e 1945 foram analisadas por Gomes (1988:229-256).

22. Ver ainda Weinstein (1996) e Dávilla (2003).

23. Como já se disse (ver nota 14), o mito da outorga (ou da dádiva) dos direitos trabalhistas foi desconstruído pela primeira vez por Moraes Filho (1952). Martins Rodrigues (1974) é expoente da corrente que sustenta a ideia de que os trabalhadores não teriam conquistado, na luta sindical e política, o que Vargas instituiu em lei, sobretudo tendo em vista sua sistematicidade e amplitude. Weffort (1978) está entre os muitos que não concordam com essa ideia. Gomes (1988), seguindo Moraes Filho, sugere que a fala operária foi expropriada por Vargas, que emergiu como autor dadivoso de demandas históricas do movimento operário. Mais recentemente, Ferreira (1997) e equipe vêm tentando resgatar a ideia de que Vargas de fato inovou na concessão dos direitos sociais. French (2004) pretende ter colocado uma pá de cal na controvérsia. Embora relevante, a discussão sobre a dádiva é lateral ao argumento central deste artigo.

24. Ver, sobre isso, Supiot (1994).

25. Ver Rosenvallon (1981), Titmuss (1963) e Castel (1998).

26. Ver, de perspectivas bastante diferentes, mas com o mesmo resultado, Durham (1973), Perlman (1977), Sales (1977), Coutinho (1980), Alvim (1997), Linhares e Teixeira (1998) e Fontes (2008). Uma resenha, ainda que limitada, é Hasenbalg (1991). Para 
os mecanismos de herança como fonte regular de expulsão dos filhos de pequenos proprietários de terra, ver Willems (1961) e Moura (1978).

27. “Numa cultura de mínimos vitais, qualquer variação nas condições de trabalho, expressa em diferenças climáticas ou de solo, ou mesmo em variantes de benevolência ou severidade do patrão, representa frequentemente a diferença fundamental entre a sobrevivência e a fome. É esse fator que torna a mobilidade uma característica tão generalizada da vida rural brasileira" (Durham, 1973:120). Nos séculos XVI e XVII, o nomadismo das populações rurais foi fortemente combatido na Europa, como mostrou Castel (1998). E a destruição dos laços que prendiam esses trabalhadores à terra no século XVIII e sua migração em massa para as cidades está na origem do capitalismo ocidental, como mostrou Marx em sua memorável análise do que ele denominou "acumulação primitiva". Ver ainda Thompson (1987).

28. Entre 1920 e 1960, Minas Gerais foi o estado com maior emigração interna líquida (1,8 milhão de pessoas deixaram o estado em quarenta anos), seguido da Bahia, com quase 900 mil, e de Alagoas, com perto de 450 mil. Ver Villela e Suzigan (2001[1973]:284). Esse montante correspondeu ao total de imigrantes estrangeiros entrados no Brasil entre 1871 e 1920. Ver Maram (1977:178). Considerando o Brasil como um todo, 5,5 milhões de pessoas emigraram de seus estados de origem para outras regiões nesses quarenta anos, sendo que São Paulo recebeu 1.5 milhão dos migrantes, o Rio, 1 milhão e o Paraná, quase 1,4 milhão (Villela e Suzigan, ibid.).

29. Para as migrações em massa no Brasil durante os ciclos da borracha, ver Silva (1982), Costa Sobrinho (1992) e Martinello (2004).

30. Apud Fontes (2008:51).

31. Garcia e Palmeira (2001:61) certamente tinham casos como esse em mente ao escrever que, "[a]s grandes cidades industriais passaram [...] a significar o universo onde havia direitos, diante do qual o mundo rural só podia aparecer como 'universo de privação' e reino do arbitrário, mundo da sujeição e do cativeiro".

32. Ver ainda Lopes (1976).

33. Neste ano é criado o Prorural, programa de aposentadoria para os trabalhadores rurais. Em 1972, as empregadas domésticas são incluídas no sistema; e, em 1973, os trabalhadores autônomos. Ver Santos (1979:35-36).

34. Isso representava meros $12 \%$ da população ocupada global, já que $70 \%$ dela ocupavam-se no campo.

35. Parte importante da explicação da titulação tão superior à própria PEA terá a ver com a habilitação das mulheres a um emprego formal, não necessariamente efetivada ao longo de seu ciclo de vida.

36. Rios e Mattos (2005:55-57 e 248) sugerem que Vargas, ao combater o coronelismo no campo, sobretudo depois de 1937, teria gerado expectativas de direitos contratuais também entre a população de trabalhadores rurais. Não por acaso, na memória de muitos descendentes de escravos, a periodização de sua cidadania tem dois momentos fundadores: a Lei Áurea e a legislação trabalhista varguista.

37. A rotatividade no Brasil é longamente estudada em Cardoso (1999 e 2000). Ver também Barros e Mendonça (1996).

38. O caráter errático das trajetórias de trabalhadores não especializados, maioria da força de trabalho migrante, não ficou na história. Como mostram Cardoso (2000), 
Guimarães (2004), Cardoso et alii. (2006) e Guimarães (2009), a instabilidade do vínculo empregatício marca a dinâmica do mercado de trabalho ainda hoje.

39. A literatura sobre o "efeito farol" do salário mínimo e outros direitos trabalhistas é abundante no Brasil. Para uma boa resenha, ver Ulyssea (2005). Lopes (1976) e Sigaud (1979) são estudos clássicos sobre a importância dos direitos na estruturação das identidades sociais dos trabalhadores da cana e dos engenhos de açúcar em Pernambuco.

40. Ver, uma vez mais, Fontes (2008).

41. Ver estudo de Montali (s. d.), disponível em http://www.dieese.org.br/cedoc/ 007171.pdf, e Lowenstein (1942). Montali sustenta que a fixação do mínimo não levou em conta os gastos reais das famílias, como previa a lei de 1938, mas apenas a média dos rendimentos inferiores a 420 mil réis.

42. Dados em IBGE (1941:94).

43. A inflação medida pelo IPC-Fipe entre janeiro e junho de 1940 para a cidade de São Paulo foi de 7,2\%, segundo série disponível em http:/ / www.ipeadata.gov.br. Como o salário mínimo passou a viger em julho de 1940, o custo de vida para essa mesma família havia se alterado em comparação a 1939, mas não a ponto de mudar qualitativamente os montantes.

44. Dados em IBGE (1941:94). O gasto total médio de uma família como essa na capital federal foi de 2,4 contos de réis em 1939.

45. Ou seja, a inflação global de 1940 a 1944 foi de pouco menos de $57 \%$, e o reajuste do salário mínimo, de pouco menos de $59 \%$.

46. Os cálculos foram todos feitos com base nos valores reais do salário mínimo encontráveis em http:/ / www.ipeadata.gov.br. Em janeiro de 1944, o salário mínimo valia o equivalente a $\mathrm{R} \$ 336,8$ (em reais de julho de 2007). Em dezembro de 1951, R\$136,4, ou quase $60 \%$ menos.

47. Como mostrou, à farta, John French (2004). Erickson (1979:104-105) sustenta que, entre 1934 e 1941, o Ministério do Trabalho, responsável pela inspeção da legislação trabalhista e por toda a regulação das relações de trabalho, gastou apenas $0,9 \%$ do orçamento federal, em média. Esse valor pode estar subestimado, já que, segundo dados de IBGE (1987:574-576), a cifra foi de quase $4 \%$ em 1939, ainda assim um valor muito baixo. Nesse ano, havia no Brasil 1,8 milhão de contribuintes para alguma caixa de previdência. Esse deve ser tomado como o tamanho aproximado do setor formal da economia, regulado pelo Estado. Os 160 mil contos de réis gastos pelo Ministério do Trabalho corresponderam a 8,9 mil réis por pessoa formalmente ocupada naquele ano, preço aproximado de uma lata de azeite, ou dois quilos de banha em 1937 (IBGE, 1941:93). Os dados sobre contribuintes à previdência são da mesma fonte do Gráfico 1.

48. Calculado com base em IBGE (1987:347-348, tabelas 7.10 e 7.12). A remuneração total paga a operários de produção no ano foi dividida pelo pessoal ocupado e dividida por 12 .

49. O salário médio no comércio foi de 420,7 mil réis no Distrito Federal e de 341 mil réis em São Paulo. Cf. Tavares de Almeida (1978:244).

50. Os dados com salários médios na indústria por estado podem ser encontrados em IBGE (Anuário Estatístico do Brasil 1941-1945:326). Ver também Tavares de Almeida 
(1978:247), que, contudo, oferece cifras discordantes com as do IBGE (fico com o valor oficial). A mesma autora (que polemiza com Francisco de Oliveira (1981[1972]) acerca do efeito do salário mínimo sobre as remunerações industriais, sustentando que houve ganhos para os trabalhadores de menor remuneração, enquanto Oliveira sustenta a ideia de que o mínimo puxou para baixo os maiores salários) adverte que os salários médios na indústria, captados pelo IAPI, estavam superestimados. Logo, eram ainda mais baixos do que as figuras aqui transcritas. Werneck Vianna (1999) toma partido de Francisco de Oliveira.

51. A penúria do trabalhador industrial no Distrito Federal no período foi captada, dentre outros, por Fischer (2008).

52. Cf. dados de inflação em http:/ / www.ipeadata.org.br.

53. Conforme argumentaram Werneck Vianna (1999) e Skidmore (2003).

54. Cálculo do salário médio efetuado segundo a mesma metodologia exposta na nota . No Anuário Estatístico do Brasil de 1950, do IBGE, o salário médio pago em julho de 1949 teria sido de Cr\$926, calculado com base em informação dos contribuintes do Instituto de Aposentadorias e Pensões dos Industriários - IAPI (cf. p. 328). Essa fonte, porém, superestima o valor real pago a operários de produção, por incluir também pessoal administrativo. IBGE (1987) permite separar os operários dos demais ocupados.

55. Ver Gomes (1988).

56. Para a reposição total da inflação, o salário médio no Distrito Federal deveria ser de Cr\$1.150,00.

57. Segundo dados do censo demográfico, tabulados para este trabalho.

58. Idem. No serviço público, $65 \%$ dos ocupados ganhavam até um salário, $69 \%$ no comércio.

59. Dados em Souza (1971:123).

60. Ver IBGE (1987:75). Trata-se da renda do trabalho, tal como declarada pelas pessoas nos censos demográficos. Subestima, portanto, a distribuição real da riqueza, que é certamente mais concentrada do que isso. Um experimento comparando a renda declarada na Pesquisa Nacional por Amostra de Domicílios (PNAD) com aquela medida pela Pesquisa de Padrão de Vida (PPV) constatou que a renda do trabalho declarada subestima a renda efetivamente recebida em perto de $40 \%$. Ver Barros et alii. (2007).

61. Como longamente explorado em Santos (2006).

62. A má-fé de parte da elite dirigente sob Vargas, incluindo o próprio, foi sustentada por French (2004) e Levine (1998).

63. Como o fazem Levine (1998), French (2004), Fischer (2008) e, em menor medida, Weinstein (1996).

64. Como afirmou Werneck Vianna (1999), o Estado Novo, para os trabalhadores, começou depois do fracassado levante da Aliança Nacional Libertadora em 1935.

65. A esse propósito, ver Paoli (1988), Weinstein (1996), Negro (2004) e Santana (2001).

66. Apenas nos anos 1980 aqueles símbolos foram eficazmente circunscritos por um renovado movimento operário como herança a ser superada. Lula, como líder sindical, dizia que "a CLT é o AI-5 do trabalhador", referindo-se ao controle dos sindicatos e da negociação coletiva pelo Estado, não à legislação de proteção do trabalhador indi- 
vidual. Mas o projeto do "Novo Sindicalismo" de superação do legado varguista seria atropelado pelo neoliberalismo dos anos 1990, e os trabalhadores brasileiros viram-se na situação de precisar defender a CLT e os direitos que o Estado passou a querer extinguir ou flexibilizar. Analisei esses processos em Cardoso (2003).

\section{REFERÊNCIAS BIBLIOGRÁFICAS}

ALVIM, Rosilene. (1997), A Sedução da Cidade: os Operários-Camponeses e a Fábrica dos Lundgren. Rio de Janeiro, Graphia.

BARROS, Ricardo P. de e MENDONÇA, Rosane. (1996), “Flexibilidade do Mercado de Trabalho Brasileiro: uma Avaliação Empírica", in J. M. Camargo (org.), Flexibilidade do Mercado de Trabalho no Brasil. Rio de Janeiro, Editora FGV, pp. 157-201.

BARROS, Ricardo P. et alii. (2007), “A Desigualdade de Renda no Brasil Encontra-se Subestimada? Uma Análise Comparativa com Base na PNAD, na POF e nas Contas Nacionais". Textos Para Discussão, Rio de Janeiro, IPEA, no 1263.

BÉRTOLA, Luis et alii. (2009), Income Distribution in Brazil: 1870-1920. Trabalho apresentado na miniconferência A Comparative Approach to Inequality and Development: Latin America and Europe Instituto Figuerola, Madrid, Universidad Carlos III, 8-9 de maio.

CARDOSO, Adalberto M. (1999), Sindicatos, Trabalhadores e a Coqueluche Neoliberal: A Era Vargas Acabou? Rio de Janeiro, Editora FGV.

. (2000), Trabalhar, Verbo Transitivo. Destinos Profissionais dos Deserdados da Indústria Automobilística. Rio de Janeiro, Editora FGV.

. (2003), A Década Neoliberal e a Crise dos Sindicatos no Brasil. São Paulo, Boitempo.

. (2010), A Construção da Sociedade do Trabalho no Brasil. Sociabilidade Capitalista, Padrões de Justiça e Persistência das Desigualdades. Rio de Janeiro, Editora FGV.

et alii. (2006), “Os Deserdados da Indústria. Reestruturação Produtiva e Trajetórias Intersetoriais de Trabalhadores Demitidos da Indústria Brasileira", in N. Guimarães e H. Hirata (orgs.), Desemprego: Trajetórias, Identidades, Mobilizações. São Paulo, Editora Senac, pp. 45-90.

CARDOSO, Fernando H. (1969[1962]), “Proletariado no Brasil: Situação e Comportamento Social". Mudanças Sociais na América Latina. São Paulo, Difusão Europeia do Livro.

CASTEL, Robert. (1998), As Metamorfoses da Questão Social: Uma Crônica do Salário. Petrópolis, Vozes.

COSTA SOBRINHO, Pedro V. (1992), Capital e Trabalho na Amazônia Ocidental: Contribuição à História Social e das Lutas Sindicais no Acre. São Paulo, Cortez; Rio Branco, EDUFAC. 
COUTINHO, Ronaldo do L. (1980), Operário de Construção Civil: Urbanização, Migração e Classe Operária no Brasil. Rio de Janeiro, Achiame.

DÁVILLA, Jerry. (2003), Diploma of Whiteness. Race and Social Policy in Brazil, 1917-1945. Durham/London, Duke University Press.

DEAN, Warren. (1971), A Industrialização de São Paulo: 1880-1945. São Paulo, Difel.

DURHAM, Eunice R. (1973), A Caminho da Cidade. A Vida Rural e a Migração para São Paulo. 2 ed. São Paulo, Perspectiva.

ERICKSON, Kenneth P. (1979), Sindicalismo no Processo Político no Brasil. FERNANDES, Florestan. (1960), Mudanças Sociais no Brasil. São Paulo, Difusão Europeia do Livro.

FERREIRA, Jorge. (1997), Trabalhadores do Brasil. O Imaginário Popular. Rio de Janeiro, Editora FGV.

FISCHER, Brodwyn. (2008), A Poverty of Rights. Citizenship and Inequality in Twentieth-Century Rio de Janeiro. Stanford, Stanford University Press.

FONTES, Paulo. (2008), Um Nordeste em São Paulo. Trabalhadores Migrantes em São Miguel Paulista (1945-1966). Rio de Janeiro, Editora FGV.

FRENCH, John D. (2001), Afogados em Leis: a CLT e a Cultura Política dos Trabalhadores Brasileiros. São Paulo, Editora Fundação Perseu Abramo.

. (2004), Drowning in Laws. Labor Law and Brazilian Political Culture. Chapel Hill/London, University of North Carolina Press.

GARCIA, Afrânio e PALMEIRA, Moacir. (2001), “Rastros de Casas-Grandes e de Senzalas: Transformações Sociais no Mundo Rural Brasileiro", in I. Sachs et alii. (orgs.), Brasil, um Século de Transformações. São Paulo, Companhia das Letras, pp. 38-77.

GOMES, Angela de C. (1979), Burguesia e Trabalho. Política e Legislação Social no Brasil, 1917-1937. Rio de Janeiro, Campus.

. (1988), A Invenção do Trabalhismo. Rio de Janeiro, Vértice/IUPERJ.

GOMES, Flávio dos S. (2006), A Hidra e os Pântanos. Mocambos e Quilombos no Brasil Escravista (Séculos XVII a XIX). São Paulo, Editora Unesp.

GUIMARÃES, Nadya A. (2004), Caminhos Cruzados. São Paulo, Editora 34.

. (2007), Trajetórias Inseguras, Autonomização Incerta: os Jovens e o Trabalho em Mercados sob Intensas Transições Ocupacionais. Disponível em http:/ /www.centrodametropole.org.br/pdf/2007/ nadyaã03.pdf. Acessado em julho de 2007.

(2009), À Procura de Trabalho. Instituições do Mercado e Redes. Belo Horizonte, Argvmentvm.

HASENBALG, Carlos A. (1991), A Pesquisa sobre Migrações, Urbanização, Relações Raciaise Pobreza no Brasil: 1970-1990. Rio de Janeiro, IUPERJ. (Série Estudos, 82).

HUTCHINSON, Bertrand (org.). (1960), Mobilidade e Trabalho. Rio de Janeiro, Centro Brasileiro de Pesquisas Educacionais.

IBGE. (1941), Repertórios Estatísticos do Brasil. Quadros Retrospectivos. Rio de Janeiro, IBGE, vol. 1. 


\section{Adalberto Cardoso}

. (1987), Estatísticas Históricas do Brasil. Rio de Janeiro, IBGE. (Séries Estatísticas Retrospectivas, vol. 3; Séries Econômicas, Demográficas e Sociais, 1550-1985).

. (2003), Estatísticas do Século XX. Rio de Janeiro, IBGE.

(vários anos), Anuário Estatístico do Brasil. Rio de Janeiro, IBGE.

LEVINE, Robert M. (1998), Father of the Poor? Vargas and his Era. Cambridge, Cambridge University Press.

LINHARES, Maria Yedda L. e Teixeira, Francisco Carlos S. (1998), Terra Prometida. Uma história da Questão Agrária no Brasil. Rio de Janeiro, Campus.

LOPES, José Sergio L. (1976), O Vapor do Diabo. O Trabalho dos Operários do Açúcar. Rio de Janeiro, Paz e Terra.

LOPES, Juarez B. (1967), Crise do Brasil Arcaico. São Paulo, Difusão Europeia do Livro. . (1971[1964]), Sociedade Industrial no Brasil. 2 ed. São Paulo, Difusão Europeia do Livro.

LOWENSTEIN, Karl. (1942), Brazil Under Vargas. New York, The MacMillan Company.

MARAM, Sheldom L. (1977), "The Immigrant and the Brazilian Labor Movement, 1890-1920", in A. Davril e W. Dean. Essays Concerning the Socioeconomic History of Brazil and Portuguese India. Gainesville, University of Florida Press, pp. 178-210.

MARTINELLO, Pedro. (2004), A Batalha da Borracha na Segunda Guerra Mundial. Rio BranCO, EDUFAC.

MARTINS RODRIGUES, Leôncio. (1966), Conflito industrial e sindicalismo no Brasil. São Paulo: Difusão Européia do Livro.

. (1970), Industrialização e Atitudes Operárias: Estudo de um Grupo de Trabalhadores. São Paulo, Brasiliense.

. (1974), Trabalhadores, Sindicatos e Industrialização. São Paulo, Brasiliense.

MERRICK, Thomas W. (1986), “A População Brasileira a partir de 1945”, in E. Bacha e H. S. Klein (orgs.), A Transição Incompleta: Brasil desde 1945. Rio de Janeiro, Paz e Terra, vol. 1, pp. 31-72.

MONTALI, Lilia T. (s. d.), Salário Mínimo e Condição de Vida. São Paulo, DIEESE. Disponível em http://www.dieese.org.br/cedoc/007171.pdf. Acessado em junho de 2009.

MORAES FILHO, Evaristo de. (1952), O Sindicato Único no Brasil. Rio de Janeiro, ANoite.

MOURA, Margarida M. (1978), Os Herdeiros da Terra. São Paulo, Hucitec.

NEGRO, Antonio. L. (2004), Linhas de Montagem: o Industrialismo Nacional-Desenvolvimentista e a Sindicalização dos Trabalhadores. São Paulo, Boitempo/FAPESP.

OLIVEIRA, Francisco de. (1981[1972]), A Economia Brasileira: Crítica à Razão Dualista. 4 ed. Petrópolis, Vozes; São Paulo, CEBRAP.

OLIVEIRA VIANNA, Francisco J. (1922[1918]), Populações Meridionais do Brasil: HistóriaOrganização - Psicologia. 2 ed. São Paulo, Monteiro Lobato.

. (1923), Evolução do Povo Brasileiro. São Paulo, Monteiro Lobato.

. (1939), O Idealismo da Constituição. 2 ed. aumentada. São Paulo, Companhia Editora Nacional. (Coleção Brasiliana). 
Uma Utopia Brasileira: Vargas e a Construção do Estado de Bem-Estar...

(1951), Direito do Trabalho e Democracia Social: o Problema da Incorporação do Trabalhador no Estado. Rio de Janeiro, José Olympio.

(1987), Instituições Políticas Brasileiras. Belo Horizonte, Itatiaia, 2 vol.

PAOLI, Maria C. (1988), Labour, Law and the State in Brazil, 1930-1950. Tese de doutorado em História, Birkbeck College, University of London.

et alii. (1983), "Pensando a Classe Operária: Os Trabalhadores Sujeitos ao Imaginário Acadêmico". Revista Brasileira de História, vol. 3, no 6, pp. 129-149.

PERLMAN, Janice E. (1977), O Mito da Marginalidade: Favelas e Política no Rio de Janeiro. Rio de Janeiro, Paz e Terra. (Coleção Estudos Brasileiros, 18).

QUEIROZ, Maria Isaura P. (1965), O Messianismo - no Brasil e no Mundo. São Paulo, Dominus.

RIOS, Ana L. e MATTOS, Hebe M. (2005), Memórias do Cativeiro. Família, Trabalho e Cidadania no Pós-Abolição. Rio de Janeiro, Civilização Brasileira.

ROSANVALlON, Pierre. (1981), La Crise de l'Etat Providence. Paris, Seuil.

SALES, Teresa. (1977), Cassacos e Corumbas. São Paulo, Ática.

SANTANA, Marco A. (2001), Homens Partidos. Comunistas e Sindicatos no Brasil. São Paulo, Boitempo.

SANTOS, Wanderley G. dos. (1979), Cidadania e Justiça. Rio de Janeiro, Campus.

. (2006), Horizonte do Desejo. Instabilidade, Fracasso Coletivo e Inércia Social. Rio de Janeiro, Editora FGV.

SCHÜHLY, Gunther F. (1981), Marginalidade: um Estudo do "Migrante Estabelecido" no Brasil. Rio de Janeiro, PUC/Agir.

SIGAUD, Lygia. (1979), Os Clandestinos e os Direitos. São Paulo, Duas Cidades.

SILVA, Adalberto F. (1982), Ocupação Recente das Terras do Acre: Transferência de Capitais e Disputa pela terra. Belo Horizonte, UFMG.

SIMÃO, Azis. (1966), Sindicato e Estado. Suas Relações na Formação do Proletariado de São Paulo. São Paulo, Dominus.

SKIDMORE, Thomas. (2003), Brasil: de Getúlio a Castelo. 13 ed. Rio de Janeiro, Paz e Terra.

SOUZA, Alberto de M. (1971), “Efeitos Econômicos do Salário Mínimo”. A Economia Brasileira e suas Perspectivas. Rio de Janeiro, APEC, pp. 121-127.

SOUZA, Jessé. (2000), A Modernização Seletiva. Brasília, UnB.

SUPIOT, Alain. (1994), Critique du Droit du Travail. Paris: Presses Universitaires de France.

TAVARES DE ALMEIDA, Maria H. (1978), Estado e Classes Trabalhadoras no Brasil (1930-1945). Tese de doutorado em Ciência Política, USP (mimeo.).

THOMPSON, Edward P. (1987), A Formação da Classe Operária Inglesa. Rio de Janeiro, Paz e Terra, vol. 1-2.

TITMUSS, Richard M. (1963), Essays on the Welfare State. Londres, George Allen \& Unwin. 


\section{Adalberto Cardoso}

TOURAINE, Alain. (1961), “Industrialization et Conscience Ouvrière a São Paulo”. Sociologie du Travail, v. 3, no 4, outubro-dezembro.

ULYSSEA, Gabriel. (2005), “Informalidade no Mercado de Trabalho Brasileiro: uma Resenha da Literatura". Textos para Discussão, Rio de Janeiro, IPEA, no 1070.

VARGAS, Getúlio D. (1938), A Nova Política do Brasil. Rio de Janeiro, José Olympio, vol. $1-5$.

(1941), A Nova Política do Brasil. Rio de Janeiro, José Olympio, vol. 8.

VILLELA, Annibal V. e SUZIGAN, Wilson. (2001[1973]), Política do Governo e Crescimento da Economia Brasileira, 1889-1945. 3 ed. Rio de Janeiro, IPEA.

WEFFORT, Francisco. (1978), O Populismo na Política Brasileira. São Paulo, Paz e Terra.

WEINSTEIN, Barbara. (1996), For Social Peace in Brazil: Industrialists and the Remaking of the Working Class in São Paulo, 1920-1964. Chapel Hill/London, University of North Carolina Press.

WERNECK VIANNA, Luiz J. (1999[1976]), Liberalismo e Sindicato no Brasil. 4 ed. revisada. Belo Horizonte, UFMG.

WILLEMS, Emilio. (1961), Uma Vila Brasileira. São Paulo, Difusão Europeia do Livro. 


\begin{abstract}
A Brazilian Utopia: Getúlio Vargas and Welfare State Building in a Structurally Unequal Society

This article joins the persistent (and still current) effort to decipher the riddle of Brazil's equally persistent inequality. Resuming the interpretation of modern Brazil proposed by Juarez Brandão Lopes in the 1960s, the article proposes to revisit the "Vargas Era" and its historical meaning and scope, in light of the reproduction of inequalities over time. The author contends that "regulated citizenship" generated the expectation of social protection among Brazilian workers, feeding the promise of citizens' integration, which was not fulfilled, while performing the task of finally (but not definitively) incorporating workers as artifices in the Brazilian state-building process.
\end{abstract}

Key words: Vargas Era; social inequalities; regulated citizenship; migrations; state-building

\title{
RÉSUMÉ
}

Une Utopie Brésilienne: Vargas et la Construction de l'État Providence dans une Société Structurellement Inégale

Cet article s'ajoute à l'effort persistant et toujours actuel de déchiffrer l'énigme des inégalités persistantes, elles aussi, du Brésil. En reprenant l'interprétation du Brésil moderne proposée par Juarez Brandão Lopes dans les années 1960, on propose une révision de "l'Ère Vargas", de ses signification et portée historique, compte-tenu de la reproduction des inégalités au long du temps. On affirme que la "citoyenneté réglée" a fait naître chez les travailleurs une attente de protection sociale, nourrissant une promesse d'intégration citoyenne qui, même si elle ne s'est pas réalisée, a eu finalement pour tâche d'intégrer mais pas durablement, les travailleurs en tant qu'artisans du processus brésilien de construction de l'État.

Mots-clé: Ère Vargas; inégalités sociales; citoyenneté réglée; migrations; construction de l'État 